\title{
(Inter)national Art: The London Old Masters Market and Modern British Painting (1900-14)
}

\author{
Barbara Pezzini
}

\section{Introduction: Conflicting National Canons}

In his popular and successful essay Reflections on British Painting, an elderly Roger Fry — who died in September 1934, the same year of this essay's publication - criticised the art-historical use of a concept closely related to nationalism: patriotism. ${ }^{1}$ For Fry the critical appreciation of works of art should be detached from geographical allegiances and instead devoted 'towards an ideal end' that had 'nothing to do with the boundaries between nations.' Fry also minimised the historical importance of British art, declaring it 'a minor school.'2 According to Fry, British artists failed to recognise a higher purpose in their art and thus produced works that merely satisfied their immediate contemporaries instead of serving 'posterity and mankind at large.'3 Their formal choices - which tended towards the linear and generally showed an absence of the plastic awareness and sculptural qualities of other European art, especially Italian - were also considered by Fry to be a serious limitation. Fry's remarks concerning patriotism in art were directed against the aggressive political nationalism of the 1930s, but the ideas behind them had long been debated. They were, in fact, a development of earlier formalist ideas shared in part by other writers of the Bloomsbury set and popularised by Clive Bell's 1914 discussion of 'significant form.' ${ }^{4}$ For Fry, as for Bell, there was a positive lineage to be found in art, a stylistic continuum that passed from Giotto through Poussin to arrive to Cézanne. British painting, with some exceptions, was excluded from this

1 I wish to thank Susanna Avery-Quash, Marie Cambefort, Alan Crookham, Sophie Hatchwell, Scott Howie, Sam Rose, Samuel Shaw and Julia Snape, who have read drafts of this chapter and provided suggestions and insights. I also wish to thank the editors, Jan Dirk Baetens and Dries Lyna, for their perceptive comments.

2 Roger Fry, Reflections on British Painting (London: Faber \& Faber, 1934), republished in: French, Flemish and British Art (London: Chatto \& Windus, 1951), 137.

3 Fry, Reflections, 138.

4 Clive Bell, Art (London: Chatto \& Windus, 1914), 3.

(C) BARBARA PEZZINI, 2019 | DOI:10.1163/9789004291997_006

This is an open access chapter distributed under the terms of the prevailing CC-BY-NC License at the time of publication. 
standard of excellence and was accepted only when it was seen as precursor of, or connected with, European movements.

In this chapter I identify an earlier, pivotal moment in the development of this mindset in the London art world. This occurred at the beginning of the twentieth century, a period that witnessed an intensifying of the discussions about the placement of historical and contemporary British painting within the canon of European art in parallel with an unprecedented commercial and scholarly growth of interest for the international art of the past. The timeframe of my enquiry spans the turn of the century until 1914. The latter date is concomitant with the epochal changes in the national and international dynamics brought forward and accelerated by the Great War. This is also the date of Bell's text on significant form and of the Whitechapel Gallery exhibition Twentieth Century Art, a celebrated show that traced the origin, development and early divisions of British modernism. ${ }^{5}$ By this time the political and artistic paradigm had shifted.

I deal here with a double set of interactions: between the national and the international and between the past and the present. In fact, I explore how (British) national artists of the present dealt with an international (European) past. In investigating the national/international tension, I address the main research question of this volume, namely, how the increasing internationalisation of the art world simultaneously challenged and reinforced questions regarding national art. In this chapter I will ask how a booming art market in London, with its circulation of goods and ideas, was a force for international exchange and yet how the increased comparison with other nations' artistic products contributed to an increased reflection on national art. This relatively straightforward process, at the time and in the place under investigation here, was enriched and complicated by the fact that a very large and culturally dominant part of this international art belonged to the European past. This type of art broadly covered the chronological span from 1200 to 1800 (Middle Ages to neoclassicism) and was traditionally defined as old masters. ${ }^{6}$ This sector of the art market was expanding greatly in London, where such works could be

5 On the 1914 Whitechapel exhibition, see: Lisa Tickner, Modern Life and Modern Subjects: British Art in the Early Twentieth Century (New Haven - London: Yale University Press, 2000), $1-10$.

6 A caveat on this term is needed. "Old masters" is a definition fraught with exclusion (of gender first of all) and inaccuracy, for instance, its chronological and geographical boundaries are not defined. It is adopted here for historical reasons, and for want of a better name. Barbara Pezzini and Susanna Avery-Quash are jointly editing a collection on the old masters market from the Napoleonic era to the Great Depression, forthcoming, 2020. 
purchased, and seen, from a growing variety of outlets. ${ }^{7}$ The contact with the art of the European past afforded by these commercial events, however, was more than an occasion for profit and consumerism: it created a cultural opportunity that generated fruitful comparative reflection. Here I illustrate the results of such commercial, critical and stylistic conjunctions and show how British artists were directly and deeply involved with the art of the past, not merely in its study and collecting, but also in its commerce.

The notion of turning to the old masters is a recurring element in art, and a conscious reference to older European artists had been present in Britain since at least the eighteenth century. ${ }^{8}$ Victorian artists have often been described as dependent on prototypes and precedents from the old masters. ${ }^{9}$ Within this general paradigm, however, each generation negotiated a different stylistic relationship with the art of the European past. Here I analyse the modalities through which British artists of the turn of the century sought their inspiration from the old masters. I argue that, in a general crisis of the market for modern academic painting, these artists not only created alternative circuits of commerce in artists' clubs and associations, but they also latched onto the trade of old masters to market their own works. The newly developed structures of this commerce - highly visible, displayed in fashionable galleries, and a much-discussed topic in new platforms of criticism - were a fundamental contribution to the dissemination and formation of modern British painting.

How is my enquiry placed within the wider panorama of British art and what does it add to its study? In the framework of my investigation - the London art world at the turn of the century - many different styles and influences coexisted to make British painting very diverse. For instance, academic historical and genre painting, still making use of a highly descriptive and detailed style, with well-defined contours, smooth surfaces and illusionistic perspective, was produced simultaneously with late Pre-Raphaelite offerings. Some artists conversed with European symbolism in a freer, looser pictorial style. In the

7 Pamela Fletcher's London Gallery Project notes only four large dealers around Pall Mall and the Bond Street area in 1860 and thirty-two in 1900. This is perhaps more reflective of the increased visibility of the trade, rather than expansion of the trade itself, but the increase in visibility is significant per se. See: http://learn.bowdoin.edu/fletcher/london-gallery/map/ (accessed January 2018).

8 On the significance that, for instance, the Renaissance had in Victorian and Edwardian times, see the essays in: John E. Law and Lene Østermark-Johansen, eds., Victorian and Edwardian Responses to the Italian Renaissance (Burlington - Farnham: Ashgate, 2005).

9 The relationship between the Victorians and the old masters is the subject of: Hilary Fraser, The Victorians and Renaissance Italy (Oxford: Wiley-Blackwell, 1992) and, more recently, Elizabeth Prettejohn, Modern Painters, Old Masters: The Art of Imitation from the Pre-Raphaelites to the First World War (New Haven - London: Yale University Press, 2017). 
case of landscape painters, many continued a long-standing British thematic tradition, while others absorbed and disseminated the lessons of French impressionism. ${ }^{10}$ The style of James Abbott McNeill Whistler, a highly successful American-born painter (d. 1903), who spent the majority of his life in Britain and was active and influential in artists' associations there, also had a great impact. ${ }^{11}$ Such diversity was amplified by many painters' concurrent adoption of contrasting styles. As pointed out by Kenneth McConkey, modern British art has been critically re-ordered in, and somehow reduced to, a coherent narrative of progression towards a homogenised European modernist style, in which the coveted status was what Charles Harrison defined as the 'most advanced."12 Within this general interpretation, great attention has been given to the development of a British avant-garde in the course of the new century. Roger Fry, who was at first engaged with the type of non-modernist art we discuss here and then around 1910 changed his critical allegiance and pictorial style to a French-inspired modernism, was at the forefront of this critical ordering in Britain, which de facto aimed to align British art production with French modernism. Following this critical paradigm shift, artists who, as McConkey effectively puts it, did not 'consciously position themselves on the modernist map,' have been less explored and their work interpreted merely as moderately modern or outright conservative. ${ }^{13}$ In this chapter I wish to restore some of the complexity to the British art world at the time. Like McConkey, I focus on works that have been excluded from the history of art by a reductive modernist mapping and, instead of interpreting them as a mere nostalgic episode, centred on isolated - and insular - topics, I connect their chosen subjects and style with topical concerns, notably the scholarly study of the art of the past

10 See on the art of the time: Elizabeth Prettejohn, "Walter Pater and Aesthetic Painting," in After the Pre-Raphaelites: Art and Aestheticism in Victorian England, ed. Elizabeth Prettejohn (New Brunswick: Rutgers University Press, 1999), 36-58; Kenneth McConkey, Memory and Desire: Painting in Britain and Ireland at the Turn of the Twentieth Century (Burlington - London: Ashgate, 2002), esp. 19-37; Stephen Calloway, "Tired Hedonists, the Decadence of the Aesthetic Movement," in The Cult of Beauty: The Aesthetic Movement 1860-189o, ed. Stephen Calloway (London: Victoria and Albert Museum Publications, 2011), 233-5.

11 See on Whistler: Robin Spencer, "Whistler, Swinburne and Art for Art's Sake," in After the Pre-Raphaelites, 59-89. On Whistler's impact on British painting and artists' associations, see: Anne Koval, “The 'Artists' Have Come Out and the 'British' Remain: The Whistler Faction at the Society of British Artists," in After the Pre-Raphaelites, 90-114. McConkey, Memory, 9-11; Charles Harrison, English Art and Modernism (London: Allan Lane, 1981), 18 .

13 McConkey, Memory, 9-11. 
and the market for old master paintings, both of which were flourishing in London at the time.

\section{Nationalism, Internationalism and the London Art World}

According to its main historiographer, Benedict Anderson, nationalism is a specifically modern concept that prospered in nineteenth-century Europe, partly as a reaction against the forced internationalism of the Napoleonic Empire. Anderson defines nationalism as a cultural construct and describes nations as 'imagined communities' generated by social expressions that build 'solidarities,' shared hubs of knowledge such as maps, the census and museums. ${ }^{14}$ At the turn of the century, the intensification of national identity coincided with an increased internationalisation of travel, cultural exchanges and trade. At this time in London, a cosmopolitan art market coexisted with a critical reflection on national painting and collections, as protective policies of national heritage that aimed to confine and define works of art nationally, alongside which developed a transnational circulation of art. For instance, 1897 saw the opening of not only the National Gallery of British Art Millbank (already known as the Tate Gallery), but also the formation of the International Society of Painters, Sculptors and Gravers, whose first president was Whistler and whose second was Auguste Rodin.

Or again, if we take 1910 as another "snapshot" of events in the London calendar, we see that several art exhibitions exemplify the coexisting, and sometimes conflicting, matters of nationalistic definition and cosmopolitan striving. At White City, the Japan-British Exhibition stretched for over 22,00o square metres, had over 8 million visitors in six months and showed examples of Japanese life and arts..$^{15}$ In modern art Roger Fry's international commercial exhibition, Manet and the Post-Impressionists, opened at the Grafton Galleries, featuring works by Édouard Manet, Paul Cézanne, Paul Gauguin, Vincent van Gogh and others. The exhibition is now widely accepted as the keystone of the diffusion of European modernism in Britain. ${ }^{16}$ Another major, but much

\footnotetext{
14 Benedict Anderson, Imagined Communities: Reflections on the Origin and Spread of Nationalism (London - New York: Verso, 1983), 163-86.

15 Ayako Hotta-Lister and Ian Nish, eds., Commerce and Culture at the 1910 Japan-British Exhibition: Centenary Perspectives (London: Global Oriental, 2012).

16 Much has been written on Fry's Post-Impressionist exhibitions, notably: Anna Gruetzner Robins, "Marketing Post-Impressionism: Roger Fry's Commercial Exhibitions," in The Rise of the Modern Art Market in London, 1850-1939, eds. Pamela Fletcher and Anne Helmreich (Manchester: Manchester University Press, 2011), 85-97.
} 
less investigated, exhibition of that year was the Whitechapel Gallery show Twenty Years of British Art, which aimed to establish the scope and identity of national contemporary art. ${ }^{17}$ This exhibition-organised by the Whitechapel Gallery's director, Charles Aitken, with a committee that included the artist George Clausen, the artist-critic D.S. (Dugald Sutherland) MacColl and the artist-critic-administrator Charles Holmes-showed 569 contemporary works by 203 artists, including Charles Shannon, Charles Conder, William Rothenstein, Margaret Gere and Henry Tonks. The old masters were also exhibited in 1910 with shows of both national and international scope. At the Royal Academy, the winter exhibition Old Masters and Deceased Masters of the British School displayed, among others, several Northern Italian Renaissance works from the collections of Robert Henry Benson and from the dealers Thomas Humphry Ward and Charles Davis. The Renaissance Italian painters of Umbria were admired by Fry at the Burlington Fine Arts Club, which showed works attributed to Fiorenzo di Lorenzo, Pinturicchio, Perugino and Raphael. ${ }^{18}$ Historical British painting, then defined by the axis Reynolds-Gainsborough-RomneyHoppner-Turner-Constable, was seen at Agnew's yearly exhibitions at their Bond Street gallery. These shows were reviewed with increasingly diminishing enthusiasm by Claude Phillips in the Daily Telegraph, as the critical interest for British portraiture started to grow thin. ${ }^{19}$ Those institutional and commercial exhibitions, albeit very different, shared the aim of re-mapping and re-ordering the art of the past as well as that of the present, both along national and international lines. They were part of a more general impetus already begun in the nineteenth century that took an increasingly visible intellectual, spatial and commercial form in the new century. To fully comprehend such complex intertwining of national/international and past/present, we should begin by exploring the four main components of such interaction: art institutions, art market, art writers and artists.

17 There is no contemporary scholarship on Twenty Years of British Art (London: Whitechapel Art Gallery, May-June 1910). D.S. MacColl reviewed the exhibition in The Burlington Magazine of July 1910, 220-30. This show also contained British works collected by the dealer Hugh Lane that were soon to be donated to the collection of the National Gallery of South Africa in Cape Town, see: Jillian Carman, Uplifting the Colonial Philistine (Johannesburg: Wits University Press, 2006), 196-206. The Burlington Magazine is hereafter cited as $B M$.

18 Roger Fry, "The Umbrian Exhibition at the Burlington Fine Arts Club," $B M 16$ (1910): $267-74$.

19 Claude Phillips's reviews for the Daily Telegraph are collected in: Criticisms of Exhibitions of Pictures Held in London 1869-1912 (London: privately printed, 1912). A copy can be found at the National Gallery Library, Shelfmark NC395London Roy $=5$ 1870-1912. 


\section{Art Institutions and the Definition of National Art}

London art institutions were experiencing a period of rapid change and development. Their interactions were sometimes fraught with conflict and such disputes often concerned their national, or indeed international, scope and function. New museums, such as the Tate Gallery (1897), Wallace Collection (1900) and Whitechapel Gallery (1901) opened, and existing ones, such as the National Portrait Gallery and the Victoria and Albert Museum, were subject to expansion and to practical as well as intellectual re-organisation. For instance, Lionel Cust, director of the National Portrait Gallery from 1895 to 1909, supervised the 1896 move of this museum from its temporary quarters at Bethnal Green to its current location near Trafalgar Square.$^{20}$ Cust, who later became co-editor of the Burlington Magazine from 1909 to 1919, also compiled the first two catalogues of the permanent collection in 1898 and $1900 .{ }^{21}$ In 1899 the South Kensington Museum was renamed the Victoria and Albert Museum and the construction of its new building by Aston Webb commenced. The Tate Gallery itself, which only opened in 1897 , doubled its capacity and incorporated a sculpture gallery through its 1899 extension. ${ }^{22}$ The reputation of the Royal Academy was in decline, whereas the Tate Gallery's and National Gallery's influence was rising and their collections growing. ${ }^{23}$ As Brandon Taylor has pointed out, the situation was 'set for a radically revised relationship between the Tate and the Royal Academy over what was the legitimate European art of the day. ${ }^{24}$ The battle, however, was not limited to the Royal Academy and the Tate Gallery. The Tate Gallery's and the National Gallery's different responsibilities as repositories of historic and modern, national and international paintings were also the subject of lengthy and often-contested negotiations and exchanges in collection holdings. To clarify such a complicated situation, and to attempt to establish some form of protection for the exodus of national

20 On the early history of the National Portrait Gallery, see: Brandon Taylor, Art for the Nation: Exhibitions and the London Public, 1747-2001 (Manchester: Manchester University Press, 1999), 92-9.

21 Lionel Cust, Historical and Descriptive Catalogue of the Pictures, Busts, \&c. in the National Portrait Gallery (London: HM Stationery Office, 1898 and 1900).

22 Frances Spalding, The Tate: A History (London: Tate Gallery Publishing, 1998), 25.

23 Christopher Whitehead, The Public Art Museum in Nineteenth Century Britain: The Development of the National Gallery (Aldershot: Ashgate, 2005). On the early 19oos decline of the Royal Academy, see: Anne Helmreich and Pamela Fletcher, "The Periodical and the Art Market: Investigating the 'Dealer-Critic System' in Victorian England," Victorian Periodicals Review 41 (2008): 323-51. For a contemporary account, see: Anon., "Modern Pictures in the Saleroom," BM 13 (1908): 67-9.

24 Taylor, Art for the Nation, 136. 
art treasures abroad, a committee of inquiry, headed by the National Gallery trustee Lord George Curzon of Kedleston, was set up in 1911, possibly in response to Robert Witt's plea in The Nation and its Art Treasures. ${ }^{25}$ During a six-day-long hearing, influential art world professionals were consulted. These included Charles Aitken (keeper of the Tate Gallery), Roger Fry (editor of the Burlington Magazine), Robert Ross (former director of the Carfax Gallery and art critic for The Morning Post), D.S. MacColl (keeper of the Wallace Collection) and others. The remit of the committee was to discuss 'the retention of important pictures in this country and other matters connected with the national collections,' namely, the re-ordering, and possible re-distribution, of works in the London museums. ${ }^{26}$ The ensuing 1915 Curzon Report recommended that:

The object to be kept in view for the Tate Gallery, shall be its gradual conversion into a gallery of British art (not exclusively modern British art), the National Gallery continuing to exhibit the acknowledged masterpieces of the British school alongside the masterpieces of foreign schools, but the remaining British pictures being transferred by degrees to the Tate Gallery. $^{27}$

Such a division posited difficult choices: not only to establish what constituted the historic British school of painting and its 'masterpieces,' but also to select which contemporary works were truly representative of its modernity and what relationship they had with the development of art history as a whole. ${ }^{28}$ The decision was made that a museum that carried the name 'National' would be mostly dedicated to the international art of the European past, within which British art was seen as an increasingly minor episode.

25 Robert Witt, The Nation and its Art Treasures (London: Heinemann, 1911). I am indebted to Alan Crookham for this reference.

26 The Curzon Report is officially known as: Report of the Committee of Trustees of the National Gallery Appointed by the Trustees to Enquire into the Retention of Important Pictures in this Country and Other Matters Connected with the National Art Collections (London: HMSO, 1915), 2; hereafter cited as Curzon Report.

27 Curzon Report, 39. On the division of the Tate and National Gallery's collections, see: Alan Crookham, "Confronting Modernity: The Establishment of the British National Collection of Modern Foreign Art 1914-1918" (paper presented at the conference Mars and Museum: European Museums During the First World War, Berlin, Bode Museum, 19 September 2014). I wish to thank Alan Crookham for the access to his as yet unpublished paper.

28 Curzon Report, interview with Sidney Colvin, 25 November 1912, 11-12; Charles Aitken, 26 November 1912, 18-20 and 24-5; Roger Fry, 28 November 1912, 50-51. 


\section{The Art Market: The Rise of the Old Masters}

There was also a rapid development in the London art trade. Pamela Fletcher, focussing on the market for contemporary painting, has traced the swift expansion of the commercial gallery, noting how an expanded set of commercial structures and networks was already in place at the turn of the twentieth century. ${ }^{29}$ Thomas Bayer and John Page, using a different set of data from auction sales, have also demonstrated how, by 1900, London's secondary art market had expanded into a fully integrated network of international dealers where many galleries were connected with international artists and art writers and had branches in Europe, the United States and worldwide. ${ }^{30}$ This expansion continued in the first decade of the twentieth century. Some dealers-like Frank Hyams, who sold art from New Zealand - were highly specialised, but the trade for paintings remained quite general, and the primary and secondary markets were often combined (Fig. 4.1). Modern, old, national and international paintings were sold by the same main platforms: dealers, galleries and auction rooms. If the scope of their stock was similar, there were, however, clear distinctions between the different types of commercial spaces.

At the top end of the market, the larger dealers-Agnew's, P\&D Colnaghi and, later, Duveen - were situated around Pall Mall and Bond Street. These companies, which often began as print sellers or other art trade shops (such as framers), increasingly specialised in paintings and, as we shall see, in old masters, as those provided higher returns. Dealers and their associated advisers, famously Bernard Berenson and Otto Gutekunst for P\&D Colnaghi and Charles Fairfax Murray for Agnew's, functioned mainly as expert mediators or advisers, either purchasing works at auction or directly from their owners. ${ }^{31}$ As Agnew's stock books show, these successful businesses often negotiated large numbers of important transactions, made considerable profits and dealt with

29 Pamela Fletcher, "Shopping for Art: The Rise of the Commercial Art Gallery, 1850s-189os," in The Rise of the Modern Art Market, 47-64.

30 Thomas M. Bayer and John R. Page, The Development of the Art Market in England: Money as Muse 1730-19oo (London: Pickering \& Chatto, 2011), 1-12.

31 On Berenson and Colnaghi, see: Jeremy Howard, "Art, Commerce, and Scholarship: The Friendship between Otto Gutekunst of Colnaghi and Bernard Berenson," in Bernard Berenson: Formation and Heritage, eds. Joseph Connors and Louis A. Waldman (Princeton: Harvard University Press, 2014), 33-68. On Fairfax Murray, see: Paul Tucker, "Responsible Outsider: Charles Fairfax Murray and the South Kensington Museum," Journal of the History of Collections 14 (2002): 115-37; Id., "Eyesight, Knowledge, Argument: Charles Fairfax Murray on 'Scientific' Connoisseurship," Studi di Memofonte 12 (2014): 106-43. 


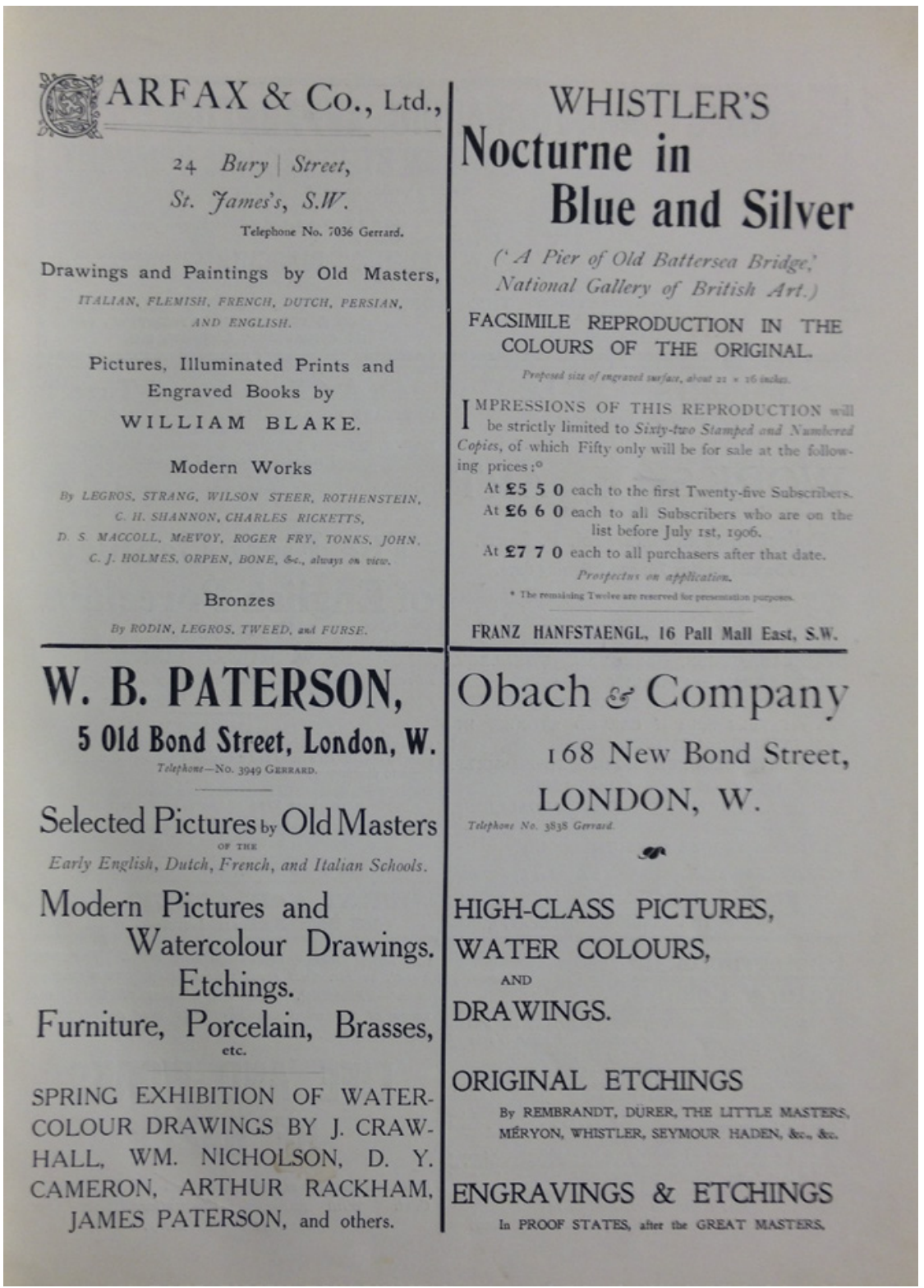

FIGURE 4.1 Advertisements of London commercial galleries, The Burlington Magazine (March 1903) 
aristocracy, wealthier collectors and major international museums. ${ }^{32}$ They were especially keen to establish a strong relationship with museums in Britain, which, consequently, were given works of art as gifts or sold pieces at cost or at a lower profit margin. ${ }^{33}$ Several of these larger firms, such as Goupil for French and Agnew's for British art, had made large profits in the mid-nineteenth century selling modern academic art to wealthier British industrialists. At the turn of the twentieth century, however, modern British art had been abandoned by high-tier dealers. They still had occasional forays into modern art, albeit this time non-academic: one of the most interesting exhibitions of modern British painting at the time, Some Examples of Independent Art of Today, was organised in February 1906 by Agnew's director, David Croal Thomson, perhaps to test the market for this new generation of native painters. It featured works by artists who were later exhibited at Twenty Years of British Art at Whitechapel: William Strang (Fig. 4.2), Roger Fry, Charles Shannon, Charles Ricketts, William Rothenstein, D.S. MacColl, Charles Holmes, Charles Conder and many others. ${ }^{34}$

Then there were new small "boutique" galleries, where dealers often combined the roles of specialists and art critics, such as Carfax and Sackville galleries. ${ }^{35}$ Modern non-academic British art circulated more freely there, intermixed with the art of the past. These smaller galleries operated from side alleys in the Bond Street area and had an exclusive, or more often bohemian, atmosphere. Carfax, for instance, had been described as

a gallery run by dilettanti for dilettanti. Somehow it was always afternoon there, and there were always tall, vague, well-dressed men talking about

32 The Agnew's Stock Books, as well as the rest of the Agnew's archive, are now preserved at the National Gallery Archive. Between 1890 and 1905 Agnew's made a profit equivalent of five million pounds in current value dealing with works by Romney alone. For business strategies of Agnew's within the wider panorama of London dealers, see: Barbara Pezzini and Alycen Mitchell, "Marketing Miss Charlotte: Martin Colnaghi and George Romney at the Turn of the Twentieth Century," Transactions of the Romney Society 19 (2014): 4-11.

33 Practice confirmed not only from data in Agnew's Stock Books but also by Lockett Agnew's testimony in Curzon Report, 10 December 1912, 63-4.

34 Some Examples of Independent Art of To-day. English, Scottish, Irish (London: Thomas Agnew and Sons, February-March 1906), another exhibition that, albeit widely referenced, has not yet received the critical attention it deserves. Reviewed by Bernard Sickert, "Independent Art of To-Day," BM 8 (1906): 381-4.

35 On the Carfax Gallery, see: Samuel Shaw, "The New Ideal Shop: Founding the Carfax Gallery, c. 1898-1902," The British Art Journal 13 (2012): 35-43; Barbara Pezzini, "New Documents Regarding the 1902 'Fans and Other Paintings on Silk by Charles Conder' Exhibition at the Carfax Gallery," British Art Journal 13 (2012): 19-29. On the Sackville and Marlborough Galleries, see: Barbara Pezzini, "The 1912 Futurist Exhibition at the Sackville Gallery, London: An Avant-garde Show within the Old Masters Trade," BM155 (2013): 471-9. 


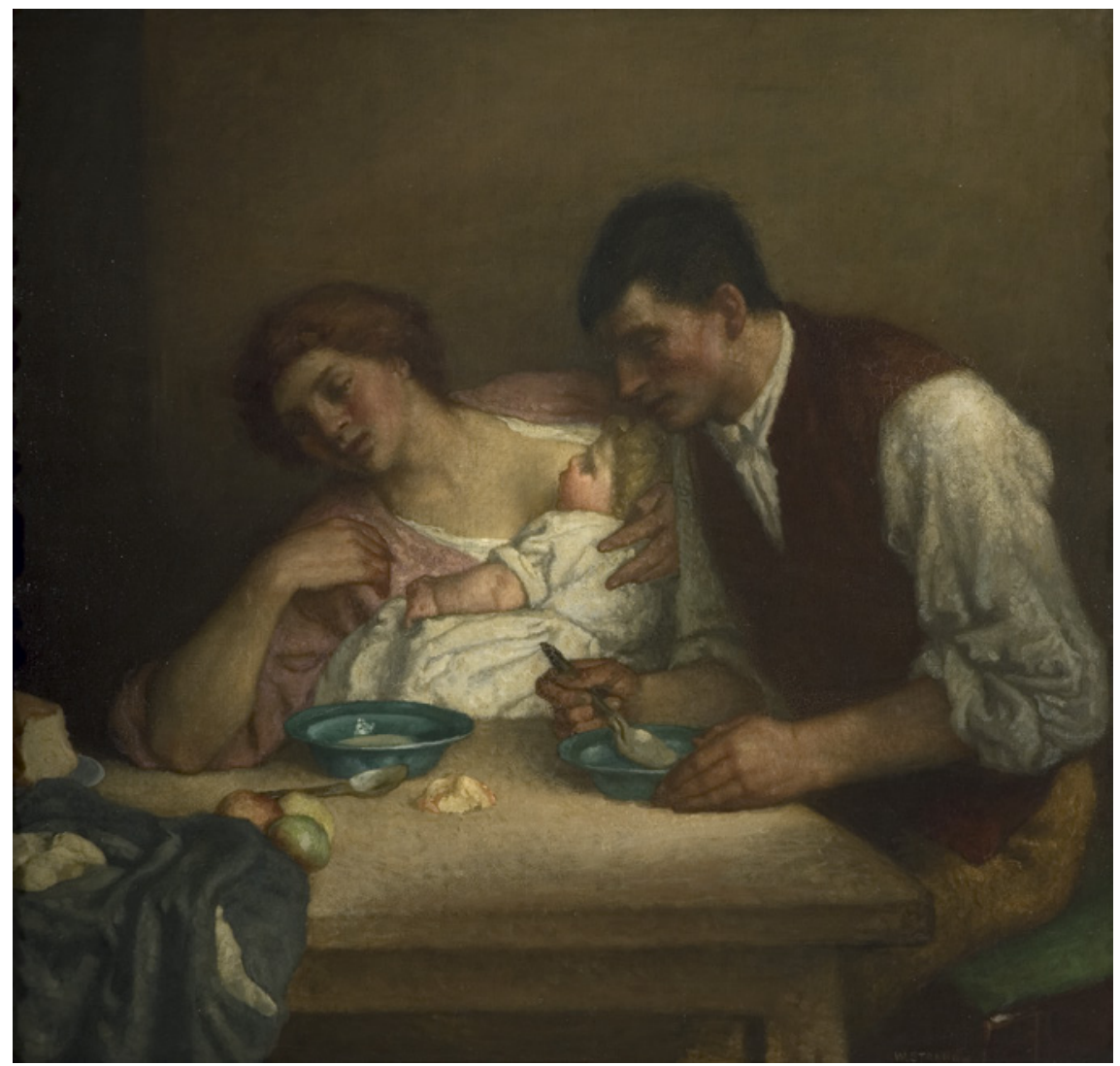

FIGURE 4.2 William Strang, Suppertime, 1905. Oil on canvas, $109 \times 115 \mathrm{~cm}$. Stoke-on-Trent, The Potteries Museum \& Art Gallery

(C) THE POTTERIES MUSEUM AND ART GALLERY

unknown poets. Upstairs in a sort of loft were stocks of Aubrey Beardsley drawings and a rare Blake painting on copper, and so it was whispered, some wonderful Botticellis in the very Chianti bottles in which they were smuggled from Italy! ${ }^{36}$

Some, like the Sackville Gallery, dealt almost exclusively in old masters but many sold both new and old art. Their activities are more difficult to reconstruct as their archives are in great part lost, but from the remaining evidence it can be gathered that theirs was mainly a network of intellectuals and their

36 From the obituary of Arthur Bellamy Clifton: "A Rare Art Dealer," The Guardian, 8 October 1932: 12-3. 
clientele consisted principally of knowledgeable, smaller collectors, although they occasionally dealt with larger transactions. ${ }^{37}$

Auction houses, then known as salesrooms-such as Christie's, Foster's, Robinson \& Fisher's and, for prints and drawings, Sotheby's - were at this time large wholesale supermarkets of secondary sale where old masters and more recent works changed hands quickly. The salesrooms were a risk-loaded place of purchase for the uninitiated, as the works for sale were not vetted and the fast rhythm of the sale necessitated split-second judgement, fast reflexes and steady nerves. ${ }^{38}$ The unpolished nature of the auction trade, however, offered potential for the discovery of hidden gems. On the floor of the salesrooms, flamboyant dealers such as William Agnew, Lockett Agnew and Martin Colnaghi of the Marlborough Gallery played theatrical battles with increasingly high bids for the treasure they had identified for their stockrooms and clients. ${ }^{39}$

If the stock of the art traders combined modern British paintings and European old masters, the financial worth of the two categories was not equal. In fact, towards the end of the nineteenth century the market in contemporary art was challenged by the secondary market in older art, which finally claimed precedence around $1900 .{ }^{40}$ The prices of old masters were then reaching unprecedented heights. Arguably, Renaissance works classified as "masterpieces," made by celebrated artists whose works rarely came on the market, had fetched increasingly high prices for a long time, although the curve became noticeably steeper after 1900. Raphael's Sistine Madonna had sold for 17,00o ducats (then the equivalent of $£ 8,500$ ) in 1754 , his Alba Madonna for $£ 14,000$ in 1836 and the Ansidei Madonna was purchased by the National Gallery in 1885 for $£_{70,000}{ }^{41}$ Then Leonardo's Benois Madonna was bought by the Tsar in Paris in 1914 for

37 On the different networks employed by dealers, see: Anne Helmreich, "Traversing Objects: The London Art Market at the Turn of the Twentieth Century," in Marketing Art in the British Isles 1700 to the Present, eds. Charlotte Gould and Sophie Mesplède (Farnham: Ashgate, 2012), 135-45.

38 Bidding at auction, with its fascination and risk, is eloquently described by Charles Holmes, Pictures and Picture Collecting (London: A. Treherne \& Co, 1903), 48-50.

39 As an anonymous writer (Claude Phillips? ACR Carter?) in the Daily Telegraph testifies, when Martin Colnaghi bought a Raeburn portrait of Sir John Sinclair for 14,000 guineas 'he was in a merry mood. Proud of his health and elasticity he pirouetted on the smooth floor, singing the refrain of Mendelssohn's I am a roamer.' Anon., "Death of Mr. Martin Colnaghi," Daily Telegraph, 25 June 1908: 8. On auction sales and dealers' marketing strategies, see: Mitchell and Pezzini, "Marketing Miss Charlotte," 4-11.

40 Bayer and Page, The Development, 179-203.

41 Figures reported by Gerard Reitlinger, The Economics of Taste, vol. 2 (London: Barrie and Rockliff, 1961), 418-9. 
$£_{310,400.42}$ What had also changed was the seemingly unstoppable rise of previously lesser-known Renaissance masters, such as Botticelli, Bellini, Crivelli and Mantegna. These artists belonged mainly to the Italian fifteenth century, the newly fashionable Quattrocento. Their critical and commercial success had previously varied, but they reached an established reputation and new commercial heights in the early twentieth century. ${ }^{43}$ There was steady growth: for instance, a relatively small cassone side by Botticelli, which sold in 1879 for $£_{294}$, achieved $£_{1,365}$ in 1892; and two small panels of Saint George and Saint Dominic by Crivelli went up from $£_{154}$ in 1875 to $£_{1,575}$ in $1905 .{ }^{44}$ But there were also spectacular price pinnacles. In March 1912 a Holy Family by Andrea Mantegna (Fig. 4.3) from the Weber Collection (New York, Metropolitan Museum of Art), which had already sold for £4,00o from Dowdeswell's in 1903, was purchased by Duveen for $£ 29,500$, at that time the highest price for a picture ever paid at a public auction. ${ }^{45}$ In 1916 Giovanni Bellini's The Feast of the Gods (now attributed to Bellini and Titian; National Gallery of Art, Washington, DC) was reported to be sold by Agnew's in conjunction with Sulley for £20,000. ${ }^{46}$ Auction sales, however, are only a part of the story, as old masters bought relatively cheaply at auction by dealers were then sold to private collectors for high returns. These transactions are harder to trace, but the newly available Agnew's stock books at the London National Gallery provide evidence of these practices. For instance, a Burial of the Virgin by Fra Angelico (Philadelphia Museum of Art) was bought on 1 July 1899 by Agnew's from Colonel Ottley for $£_{350}$ and sold to John G. Johnson on 18 July 1900 for $£ 1,500 .{ }^{47}$ An unidentified Portrait of a Lady ascribed to Tintoretto was bought on 21 October 1901 by Agnew's, Charles Fairfax Murray and Colnaghi together for $£ 2,500$ and then sold for $£ 4,300$ to the Lawrie dealership on 4 January $1902 .{ }^{48}$ It was a particularly fortunate conjunction for the old masters painting market. Their supply was unusually plentiful. The agricultural depression that began in the 1870 ; the introduction of the Settled Land Acts in 1882-90, which facilitated sales; and, finally, the introduc-

42 Reitlinger, The Economics, vol. 2, 367.

43 Susanna Avery-Quash, "Botticelli and Victorian Art Collecting," in Botticelli Reimagined, eds. Mark Evans and Stefan Weppelmann (London: V\&A Publishing, 2016), 294-310.

44 Reitlinger, The Economics, vol. 2, 255-6 (Botticelli) and 287-8 (Crivelli).

45 Anon., "Picture Sales," The Connoisseur 32 (1912): 267. The author reports that it sold for $£ 29,500$ at the Weber auction, and that Weber had bought it for £4,00o from Dowdeswell in 1903. Also reported in: Reitlinger, The Economics, vol. 2, 379.

46 Reitlinger, The Economics, vol. 2, 248.

47 Fra Angelico, Dormition of the Virgin, Agnew's Stock Books, vol. 6, stock no. 9068, National Gallery Archive, London, NGA27/1/1/8, currently Philadephia Museum of Art (Inventory number Cat. 15), bequeathed by John J. Johnson to the museum in 1917.

48 Agnew's Stock Books, vol. 6, stock no. 89, National Gallery Archive, London, NGA27/1/1/8. 


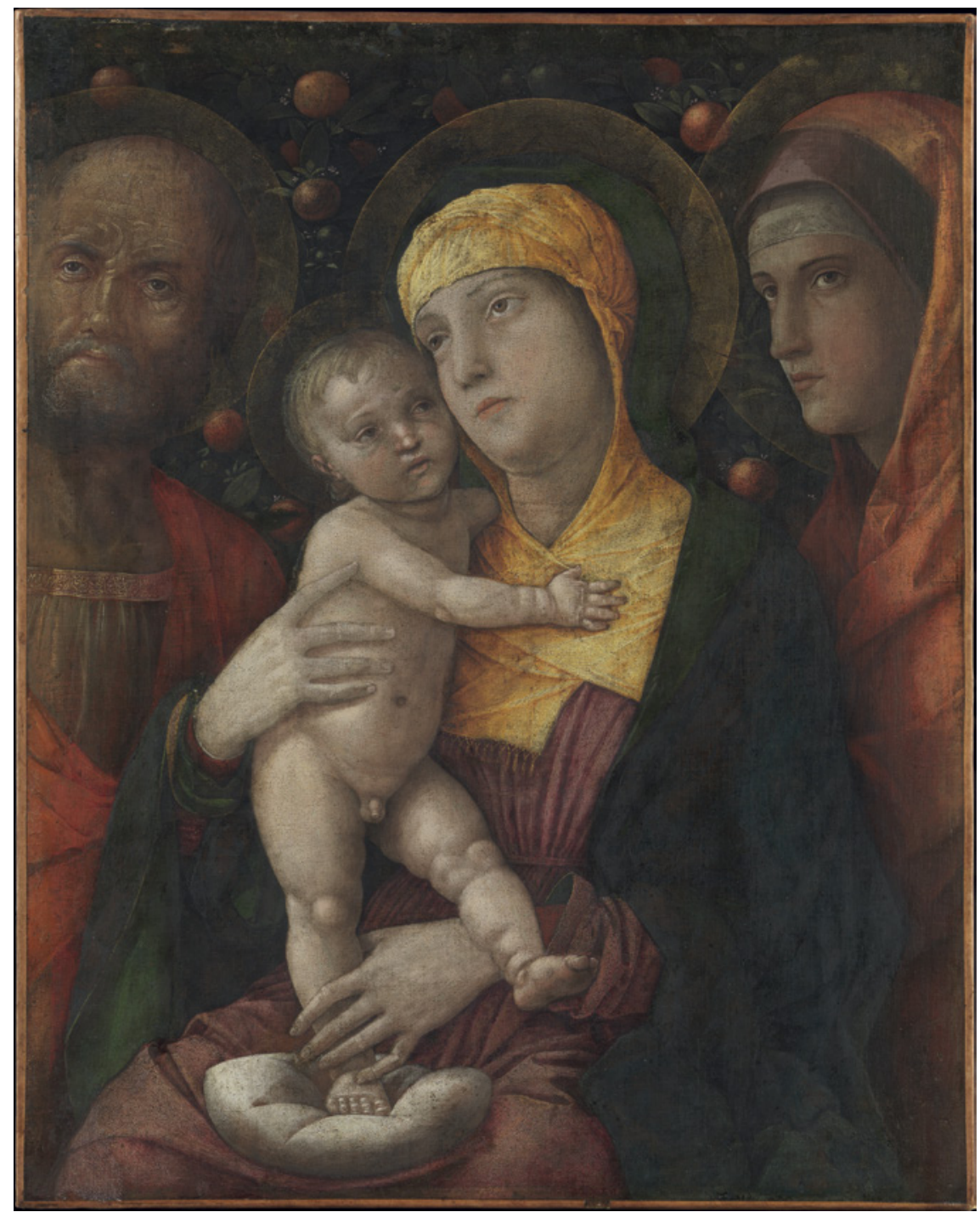

FIGURE 4.3 Andrea Mantegna, Holy Family with Saint Mary Magdalen, 1495-1500. Distemper on canvas, $57.2 \times 45.7 \mathrm{~cm}$. New York, The Metropolitan Museum of Art

(C) THE METROPOLITAN MUSEUM OF ART

tion of Death Duties in 1894 had led to a considerable amount of works of art of high quality belonging to the British aristocracy on the London market, augmented further by the high prices these commanded. There was, in fact, a great demand for them: a new collecting class of industrialists, mainly from the United States and South Africa, was on the rise, gathering these works 
in large numbers. The new collectors were more ostentatious and looked for the approval of peers and the public validation of their enterprises. They, as Kenneth McConkey and Flaminia Gennari Santori have noted, were the sort of individuals who collected to outstrip everyone else, and when they entered the market, prices rose to new heights. ${ }^{49}$ But the interest for such art was not limited to rich collectors alone. The old masters were en vogue. From expensive monographs to cheaper popular artists' biographies, from masterly photogravures to inexpensive photographs, there was a flourishing trade around the old masters, their reproductions and their associated products.

\section{Art Writers: Scholarship as a Commercial Guarantee}

At the turn of the twentieth century, art writing in Britain was in a state of flux. As in the commercial world, where contemporary art and old masters were exhibited and sold in the same spaces, in art writing the art of the past and the art of the present were treated by the same writers. Criticism of contemporary art and art historiography coexisted. Writers like Claude Phillips, D.S. MacColl, Roger Fry and Charles Ricketts reviewed contemporary and historical art alike and combined journalism and careers in art institutions. In Britain criticism of modern art modified the rules of the art writing game first when a new reviewing style, to which the claims of autonomy of art made in Whistler's 'Ten O'Clock Lecture' of 1885 were closely related, shifted the emphasis of criticism from moral exhortation to visual description. Its main proponents were George Moore of the Speaker, R.A.M. Stevenson of the Saturday Review and the Pall Mall Gazette and, above all, D.S. MacColl at the Spectator. ${ }^{50}$

A parallel shift from the moral to the descriptive also occurred in historiography. Over the course of the nineteenth century, the new research methods coming from Germany, France and Italy, where art history was already subject of study at universities, contributed to changing the study of art from a poetic experience in the manner of Ruskin into a referenced, peer-reviewed language, based on documentary sources and on what was felt to be a truly objective visual methodology known as "scientific connoisseurship." This process gained momentum in the early twentieth century. Then, expanding on

49 Regarding the American art market, but with many cross references to the British market too, see: Flaminia Gennari Santori, The Melancholy of Masterpieces: Old Master Paintings in America 1900-1914 (Milan: 5 Continents, 2003), 123-50.

50 For an overview of the New Criticism, see:John Stokes, In the Nineties (Chicago: University of Chicago Press, 1990), 34-52. 
the pioneering work of earlier scholars, such as Eastlake, Passavant, Waagen, Morelli and Cavalcaselle, the new experts continued to find in the art of the European past a fruitful field of enquiry. Novel studies were published by an increasingly developed art press with a wider circulation and higher print runs, which made them available to an ever-increasing number of readers. ${ }^{51}$ For instance, Fry's monograph on Giovanni Bellini had three editions between 1899 and $1901 .{ }^{52}$ Bernard (and Mary) Berenson's volumes on the Italian painters of the Renaissance, published between 1894 and 1907, were collected in a single volume in 1930. These were printed again and again throughout the twentieth century, translated into the main European languages and adopted as textbooks in university courses..$^{53} \mathrm{By} 1900$ art writers were no longer just critics, they were also recognised as "experts" and "connoisseurs" and possessed a series of skills that gave them the ability of identifying artists and works of art. These skills were expressed in publications, such as the monograph and catalogue raisonné, which established a list of attributed works and were thus useful for the trade. ${ }^{54}$ But art writing did not merely produce a frame of reference for commerce; it actively participated in it. Well-respected "experts" such

51 On the expansion of the book trade, see: Alexis Weedon, Victorian Publishing: The Economics of Book Production for a Mass Market 1836-1916 (Aldershot: Ashgate, 2003); Simon Eliot, "From Few and Expensive to Many and Cheap: The British Book Market 1800-1890," and Jonathan Rose, "Modernity and print I: Britain 1890-1970," both in A Companion to the History of the Book, eds. Simon Eliot and Jonathan Rose (Malden: Blackwell, 2007), 291-302 and 341-53.

52 Donald A. Laing, Roger Fry: An Annotated Bibliography of the Published Writings (New York and London: Garland Publishing, 1979), 29-33. On Fry's intellectual influence, see: Vision and Design: The Life, Work and Influence of Roger Fry, 1866-1934 (London: Arts Council Catalogues, 1966).

53 Berenson's The Italian Painters of the Renaissance was first published as Venetian Painters of the Renaissance, in 1894; Florentine Painters of the Renaissance in 1896; Central Italian Painters of the Renaissance in 1897; and finally North Italian Painters of the Renaissance in 1907. These were then collected as Italian Painters of the Renaissance in 1930, and had subsequent editions in 1932 and then several in the course of later decades. During the 1910 Roberto Longhi translated The Italian Painters of the Renaissance, published in 1936. See: William Mostyn-Owen, Bibliografia di Bernard Berenson (Milano: Electa, 1955); Ernest Samuels and Jayne Samuels, Bernard Berenson: The Making of a Legend (Princeton: Harvard University Press, 1987), 598-9. The works by the nineteenth-century pioneers, instead, garnered much less attention. For instance, Gustav Friedrich Waagen's Treasures of Art in Great Britain was published in the mid-nineteenth century and then not printed again until 1970.

54 Barbara Pezzini, "The Burlington Magazine, The Burlington Gazette and The Connoisseur: The Art Periodical and the Market for Old-Master Paintings in Edwardian London," Visual Resources 29 (2013): 154-83; Meaghan Clarke, "The Art Press at the Fin-de-Siècle: Women, Collecting and Connoisseurship," Visual Resources 31 (2015): 15-30. 
as Bernard Berenson, Wilhelm Bode and Charles Fairfax Murray had the power to connect and disconnect names to works of art, sometimes changing their fortunes, and commercial values, dramatically. A painting by the hand of a "master" was worth much more than an unidentified work, and a painting by a prominent master, such as the established Raphael or the emerging Botticelli, was worth most of all. ${ }^{55}$ As the prices of old masters were rising to unprecedented heights, the financial implications were significant-and in fact those experts had lucrative associations, either known or semi-clandestine, with major art dealers, such as Colnaghi (Berenson) and Agnew's (Bode and Murray).${ }^{56}$ Scholarship itself became a form of publicity and a guarantee: the old masters, when certified by expert approval, were then considered a sound investment, immune to the fluctuations to which other kinds of art seemed to be subjected. Art writers formed all sorts of new relations with the old masters trade: from the creation of alternative commercial circuits and the management of smaller galleries, to the organisation of exhibitions in commercial galleries and the mediation of acquisitions with the commercial world while still in public service ${ }^{57} \mathrm{New}$ periodicals that dealt specifically with the old masters, such as The Connoisseur (1901-92) and The Burlington Magazine (1903present), were founded and books were written, notably Charles Holmes's 1903 Picture Collecting, with the aim of guiding artists, collectors and scholars alike in this maze of new spaces and relations. ${ }^{58}$

\section{Artists: New Networks and Old Models}

In such a dynamic period, how did an intertwining of nationalism and internationalism manifest itself in current artistic practice? How was modern national painting situated by its contemporaries within this newly forming canon? A certain kind of national painting seemed to be in deep crisis. The highly moralistic and minutely-detailed narrative style, in which the subject matter and mimetic veracity was of utmost importance- of which a characteristic example is Mother's Darling by Joseph Clarke (1884; London, Tate Gallery, acquired

55 On Botticelli's inconsistent critical reception, see: Avery-Quash, "Botticelli and Victorian Art Collecting," 310.

$5^{6} \quad$ See footnote 31 for some secondary literature on these matters.

57 For a snapshot of the publishing world at the time and the combination of professional roles, see: Samuel Shaw, "Scarcely a Scholar: William Rothenstein and the Artist as ArtWriter in English Periodicals, ca. 1890-1910," Visual Resources 31 (2015): 45-6o.

$5^{8}$ Holmes, Pictures. 
1885) - was in critical decline. ${ }^{59}$ Such works, which were associated with the Royal Academy and had formed the backbone of the British acquisitions of the National Gallery and the Tate Gallery through the Academy-administered Chantrey Bequest, were now despised by a new generation of art writers. ${ }^{60}$ When in 1902 MacColl wrote his monumental resumé of nineteenth-century art, he excluded British academic art from his narrative, which instead centred on French impressionism. ${ }^{61}$ The art press that was connected to British painting and its diffusion by reproductive engravings, the Magazine of Art and Art Journal, was, understandably, in crisis too-in fact these journals closed respectively in 1904 and $1912 .{ }^{62}$ The demise was also commercial. Prices for lateVictorian narrative art, as Bayer and Page, and Reitlinger have shown, were falling; these works soon disappeared from the market altogether. ${ }^{63}$ It is interesting to follow some examples of such decline. These works had changed hands for very high profits in the 1860 s and 1870 . Agnew's stock books, again, bear witness to the height of the sums in question. ${ }^{64}$ A plethora of British paintings were bought by Agnew's, either directly from the artists or at the Royal Academy summer exhibitions, and re-sold for high markups. For instance, Chill October and Yes or No by John Everett Millais were bought jointly for £2,0oo

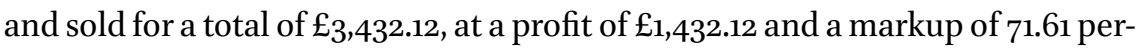
cent. ${ }^{65}$ But at the turn of the twentieth century, the tide had turned and prices declined steeply. Edwin Landseer's Lady Godiva's Prayer (Coventry, Herbert Art Gallery and Museum) was sold in 1873 by his executors for $£_{3,360}$, but in 1916 it only achieved $£ 943 .{ }^{66}$ La Siesta by John Frederick Lewis declined from $£ 1,013$ in 1877 to only $£_{115}$ in $1923 \cdot{ }^{67}$ Similarly, John Linnell's Eve of the Deluge decreased

59 When the first official guide to the Tate Gallery was published in 1897 it still focused on the subject rather than on the execution of a painting. Such descriptive catalogues, as Frances Spalding has pointed out, only reinforced visitors' expectation that every picture should tell a story and should be judged on the basis of its mimetic veracity. Spalding, The Tate, 25 .

6o Spalding, The Tate, $26-8$.

61 D.S. MacColl, Nineteenth Century Art (London: Macmillan, 1902).

62 On the demise of these magazines in a changed panorama, see: Anne Helmreich, "The Death of the Victorian Art Periodical," Visual Resources 26 (2010): 242-53.

63 Bayer and Page, The Development, 12. See also the variations in price for the period 18501910 recorded by Reitlinger, The Economics, vol. 2, 264-5, 319-20, 359-6o, 365-6 (modern art); 254-5, 289-90, 333-4, 373-4, 378-9 (old masters).

64 See the Agnew's Stock Books, vols. 1 to 3 , National Gallery Archive, London, NGA27/1/1/3 and NGA27/1/1/5.

65 Agnew's Stock Books, vol. 2, stock nos. 6270 and 6271, National Gallery Archive, London, NGA27/1/1/4.

66 Reitlinger, The Economics, vol. 2, 359 .

67 Id., 369-70. 
from $£ 1,092$ in 1872 to $£ 189$ in $1913 .{ }^{68}$ William Frith (d. 1909) saw the value of his market collapse around 1896 when he was still actively working. Frith's paintings sold for $£_{3}, 000$ to $£_{5,000}$ in the 1860s but fetched one-tenth of this value at the turn of the century. ${ }^{69}$ There were a few collectors who supported this type of academic art into the new century. For instance, Sir John Aird commissioned in 1902 The Finding of Moses by Lawrence Alma-Tadema for $£ 5,250$ plus expenses. ${ }^{70}$ These were, however, exceptions. By 1900 Agnew's, often the thermometer of British taste, dealt almost exclusively in works of, as they called them then, 'deceased masters.' In 1903, when the Henry James Turner collection of British painting was sold at auction, it was bought-in by the Tooth art dealers. The critic (and art dealer) Max Rothschild expressed his open contempt for this collection, which included works by previously successful artists such as Briton Rivière, and affirmed that a large number of its pictures had been selected for their subject matter and not their quality and were 'not worth the canvas upon which they are painted. ${ }^{71}$ The golden generation of British painters connected with the Royal Academy, whose works had exchanged hands for thousands of pounds in the 1860s-70s, was in commercial and critical decline, and there lacked a successful new cohort of academicians to replace it.

It would therefore seem unsurprising, when the art of the past experienced such a critical, commercial and popular fame and when such a success was paired with a waning interest in the immediately precedent generations, that younger artists began to associate themselves, both stylistically and commercially, with the European past and bypassed their older contemporaries, especially native ones, altogether. In fact, at the turn of the twentieth century a newly formed network of younger critics, artists and dealers rejected the previously acclaimed academic narrative painting and instead adopted compositional and technical models directly from European old masters to achieve a style that strived to be less illusionistic, less detailed and less descriptive and yet was felt to be more evocative than the immediately precedent era's attempts. A new cosmopolitan generation of London-based artists had emerged who had either trained in Paris, or who were regularly travelling between the two cities and throughout Europe. These artists grouped themselves into associations independent from the Royal Academy, such as the New English Art Club (founded in 1886) and the International Society (1897). They adopted a

\footnotetext{
$68 \quad$ Id., 371.

$69 \quad$ Id., 319.

70 Vern G. Swanson, The Biography and Catalogue Raisonné of the Paintings of Sir Lawrence Alma-Tadema (London: Garton \& Co, 1990).

71 M.R. [Max Rothschild], "The Picture Sales," The Burlington Gazette 1 (1903): 47.
} 
pictorial style that McConkey has suggestively described as a 'referential world of quote and counter quote. ${ }^{72}$ Schooled mainly at the Slade School of Art by Alphonse Legros, who keenly encouraged his pupils to copy works in public museums, these artists conversed directly with the old masters at the National Gallery. Such dialogue was a fertile ground of inspiration, which affected British figure painting from the late 1890 os onwards. The starting point was a Whistler/ Velázquez model, as clearly exemplified in William Strang's Suppertime (Fig. 4.2), but some artists had a distinct preference for Dutch and Flemish art. As McConkey points out, small, perfectly painted interiors became the distinguishing features of New English Art Club exhibitions at the turn of the century, such as in The Mirror by William Orpen (1900; London, Tate Gallery).

Charles Conder's work is a distinctive example of the coexisting denial of the visual language of the artists of the immediately preceding generation, while taking lessons from the art of the European past. Conder's work was often compared to the old masters: in 1902 Fry had noted in The Athenaeum that Conder was 'gifted with the same recklessness of invention and the same expressive inaccuracy as the cassone painters of the Renaissance. ${ }^{73}$ The Paristrained Conder, however, found his main inspiration in Antoine Watteau for his poetic interpretations, such as The Gondolier and Fête Galante, the latter quoting literally the title of Watteau's best-known compositions (Fig. 4.4). In Conder's works, like in Watteau's paintings such as the Pilgrimage to the Isle of Cythera (1717; in the Louvre since 1793), clouds rise from pools of water, and women in pink and blue silk dresses rest under verdant trees, their hands and arms often gracefully turned to the side in sinuous curves. Yet again the reference to Watteau is intensely personal in Conder and combined with a strong departure from conventions of narrative Victorian painting. Conder rejects the Victorian predilection for historically specific representation and abandons codified spatial canons. As Petra Chu writes, in Conder's art, as well as the much-mentioned nostalgia for the past and the neo-rococo revival, themes of dreams and memory anticipate Bergson-inspired motifs of the surrealist movement. ${ }^{74}$

The importance of Venetian art for Charles Shannon is especially visible in works such as The Bath of Venus (London, Tate Gallery), exhibited in 1904 at the Guildhall, and Tibullus in the House of Delia (London, Tate Gallery) and

72 McConkey, Memory, 82.

73 [Roger Fry], “Exhibitions," The Athenaeum, 17 May 1902: 632.

74 Petra ten-Doesschate-Chu, "Siegfried Bing and Charles Conder: The Many Faces of New Art," in Twenty-First-Century Perspectives on Nineteenth-Century Art: Essays in Honor of Gabriel P. Weisberg, eds. Laurinda S. Dixon and Petra ten-Doesschate-Chu (Newark: University of Delaware Press, 2008): 133-40. 


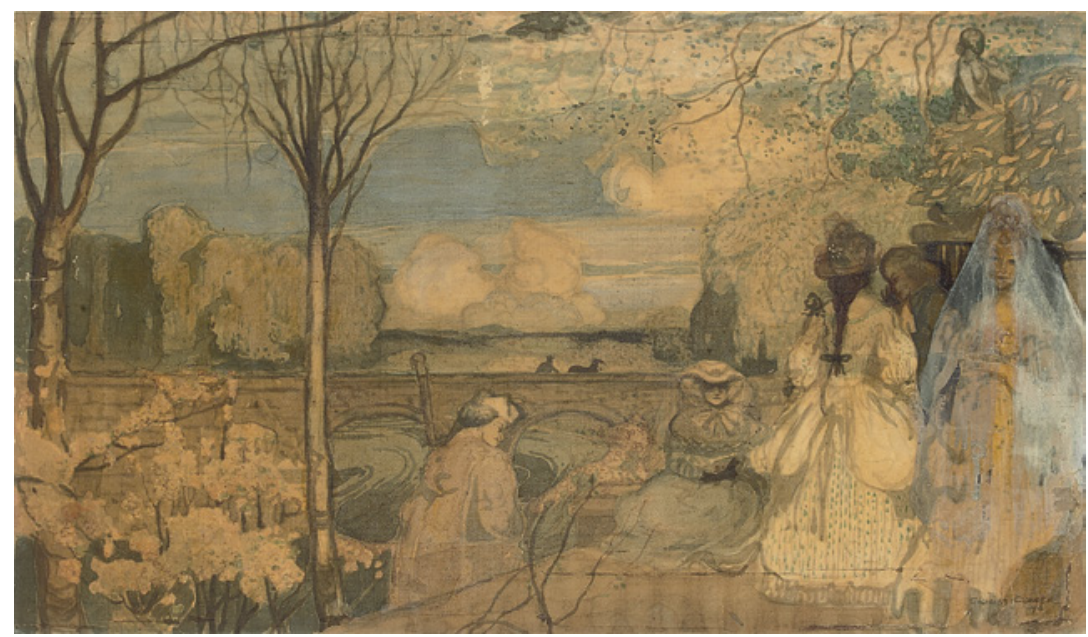

FIGURE 4.4 Charles Conder, Fête Galante, 1896. Watercolour on silk laid down on paper, $26 \times 44.7 \mathrm{~cm}$. Private collection

(C) CREATIVE COMMONS

The Mill Pond (Manchester, City Art Gallery) (Fig. 4.5), both exhibited in 1906 at the Agnew's Independent Art exhibition. ${ }^{75}$ Such Venetian inspiration is particularly noticeable in the later portrait of Hilda Moore, titled, in Renaissance style, The Lady with the Amethyst (Fig. 4.6), which shows, through a Whistlerian filter, the compositional and chromatic impact of works by Lorenzo Lotto such as the Portrait of Andrea Odoni (London, Royal Collection since 1660) and the Portrait of a Gentleman in his Studio (Fig. 4.7) in the historical collection of the Gallerie dell'Accademia in Venice, which Shannon visited with Ricketts in 1899 and 1903. The oeuvre of Shannon is more problematic to place neatly in this brief mapping of the old and the new, as the self-taught Shannon did maintain conscious connections with some of the painters, such as Dante Gabriel Rossetti, who immediately preceded him. Yet when we compare Shannon with Rossetti, we find again in Shannon that process of visual subtraction and simplification already identified in Conder. Shannon's composition is tighter and sparser than Rossetti's; his palette and psychology, as expressed through a body language of closed, defensive gestures and the absence of eye contact, are much darker in tone as well as in mood.

75 Irish Artists (London: Guildhall Museum, 1904), cat. no. 13, as The Toilet of Venus, lent by the artist; Some Examples of Independent Art of To-day. English, Scottish, Irish, Thomas Agnew and Sons, London, February-March 1906, cat. nos. 10 and 23; William C. McKeown, "Charles Shannon in the House of Delia: A Theme from Tibullus," BM $15^{2}$ (2010): 303-6. 


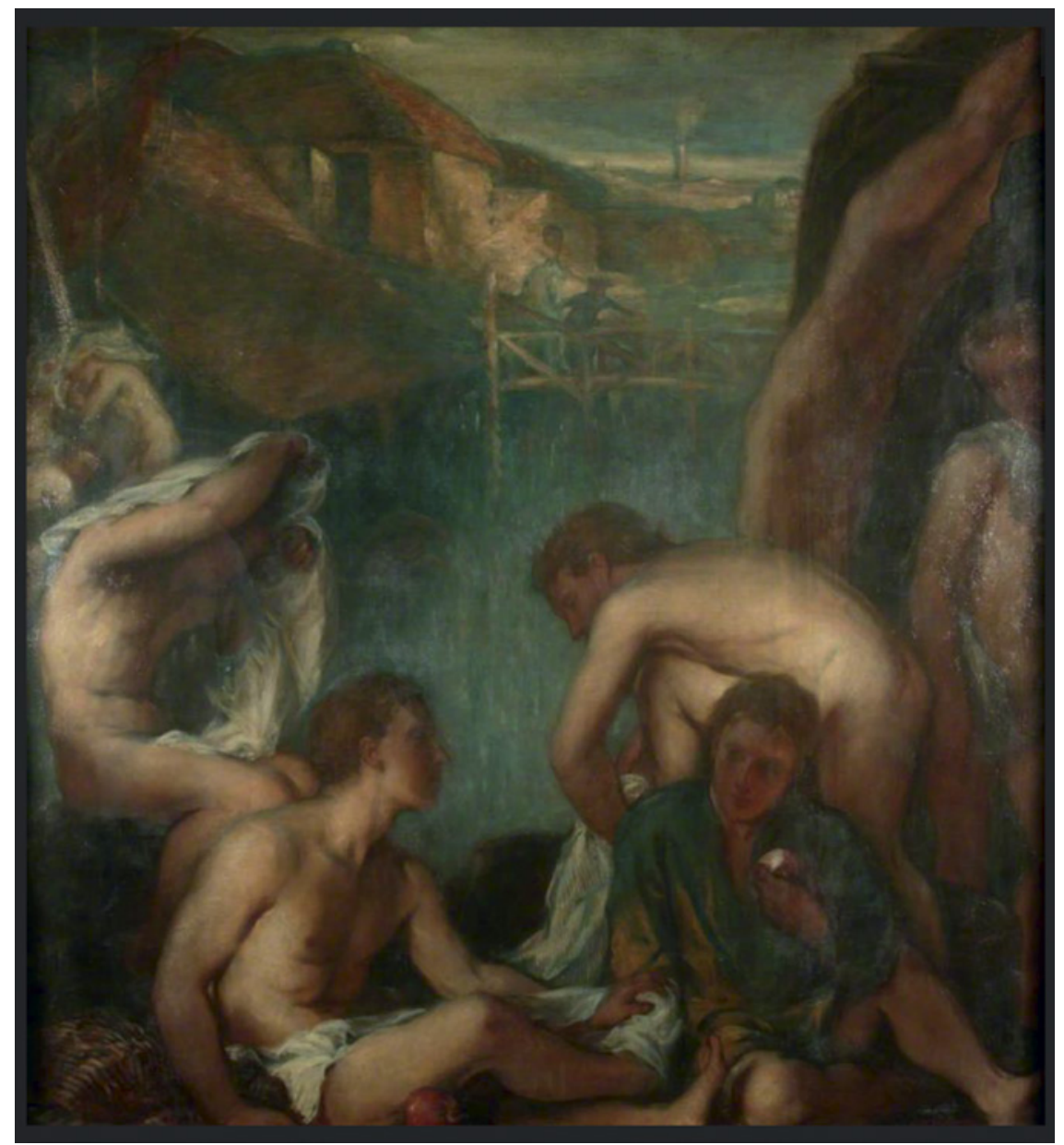

FIgURE 4.5 Charles Shannon, The Mill Pond, 1905. Oil on canvas, $109.2 \times 103.5 \mathrm{~cm}$. Manchester, Manchester Art Gallery

(C) MANCHESTER ART GALLERY

Other artists adopted a combination of models and subjects, as shown in Charles Ricketts's Crucifixion (Cheltenham Museum and Art Gallery) (Fig. 4.8), exhibited at the International Society in 1909, which fuses Spanish and Italian Mannerism but finds in El Greco's Crucifixion (Toledo, Museo de Santa Cruz) (Fig. 4.9), published by Cossío in 1908 , its principal reference. ${ }^{76}$ Yet the torn

76 "Crucifixion of Charles Ricketts, Venetian in colouring, exhibited January 1909 at the International Society," "London News," American Art News 7, 16 January 1909: 5. In April 1903 Ricketts had travelled to Madrid to write a guide to the Prado Museum, published 


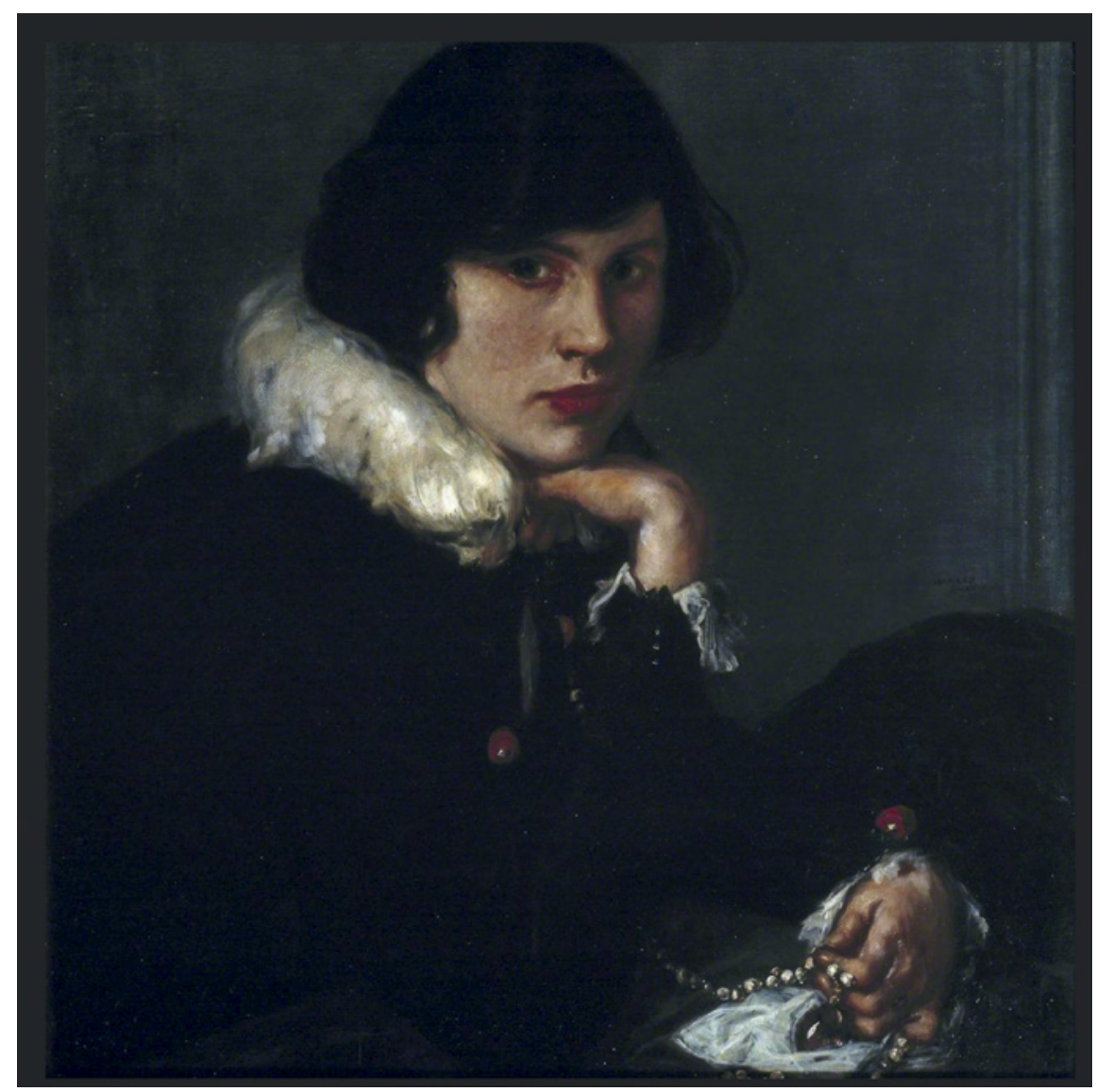

FIGURE 4.6 Charles Shannon, The Lady with the Amethyst, 1915 . Oil on canvas, $61 \times 59.7 \mathrm{~cm}$. London, Tate

(C) TATE

drapery, dark sky and dramatic palette give this work a much more sombre atmosphere that hints towards a novel psychological despair and torment. Another work of the time, William Rothenstein's The Browning Readers (1900; Bradford Museum and Art Galleries), a work that simultaneously references Whistler, Puvis de Chavannes and Dutch interiors again, captures perfectly the bidirectional current between the national and the international, the past and the present. ${ }^{77}$

later that year. See: Paul Delaney, Charles Ricketts: A Biography (Oxford: Clarendon Press, 1990), 131-6 and 161-71; Manuel B. Cossío, El Greco (Madrid: Suarez, 1908), 92.

77 I am indebted to Samuel Shaw for these observations. 


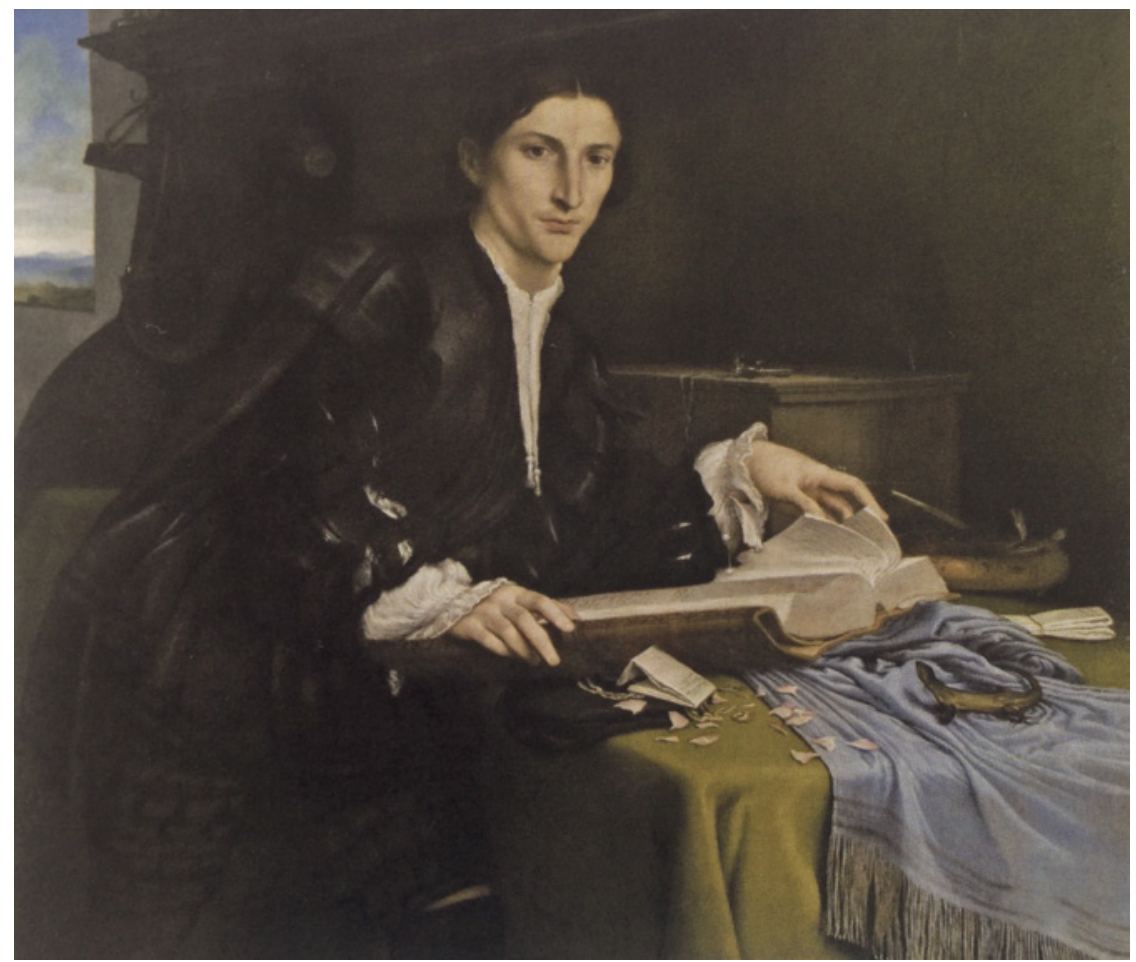

FIgURE 4.7 Lorenzo Lotto, Portrait of a Gentleman in his Study, c. 1530. Oil on canvas, $98 \times 111 \mathrm{~cm}$. Venice, Gallerie dell'Accademia

(C) GALLERIE DELL'ACCADEMIA

\section{The Old Masters of the Future? Modern British Painting and the Old Masters Market}

Within this combination of novel formal experiments and quotation of the past, the element of innovation was at times understated by art writers who preferred to emphasise the stylistic references to the old masters as part of a marketing strategy. For instance, the commercial connection between the younger British artists and the old masters was openly formulated by Charles Holmes in Pictures and Picture Collecting (1903). Holmes specifically suggested the purchase of 'serious' works that contained 'what is best in the art of the past.' Holmes mentioned by name the artists treated here and introduced them as the old masters of the future: Charles Conder, William Orpen, Charles Ricketts, Charles Shannon and William Strang. These artists were presented as commercially viable too, as they were 'reasonable in price' and 'a very safe 


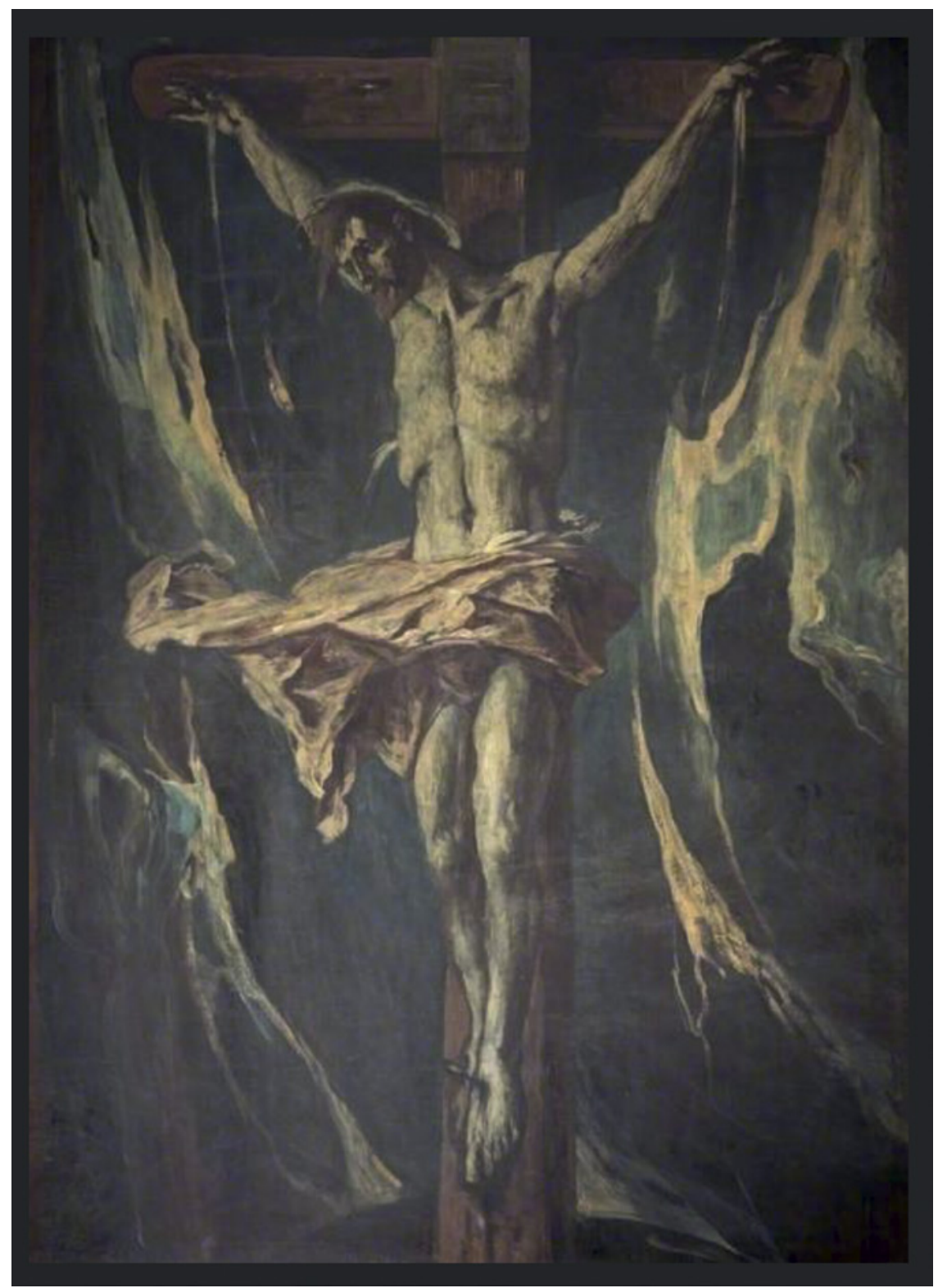

FIGURE 4.8 Charles Ricketts, Crucifixion, c. 1908. Oil on canvas, $200 \times 133.5 \mathrm{~cm}$. Cheltenham Art Gallery and Museum

(C) CHELTENHAM ART GALLERY AND MUSEUM 


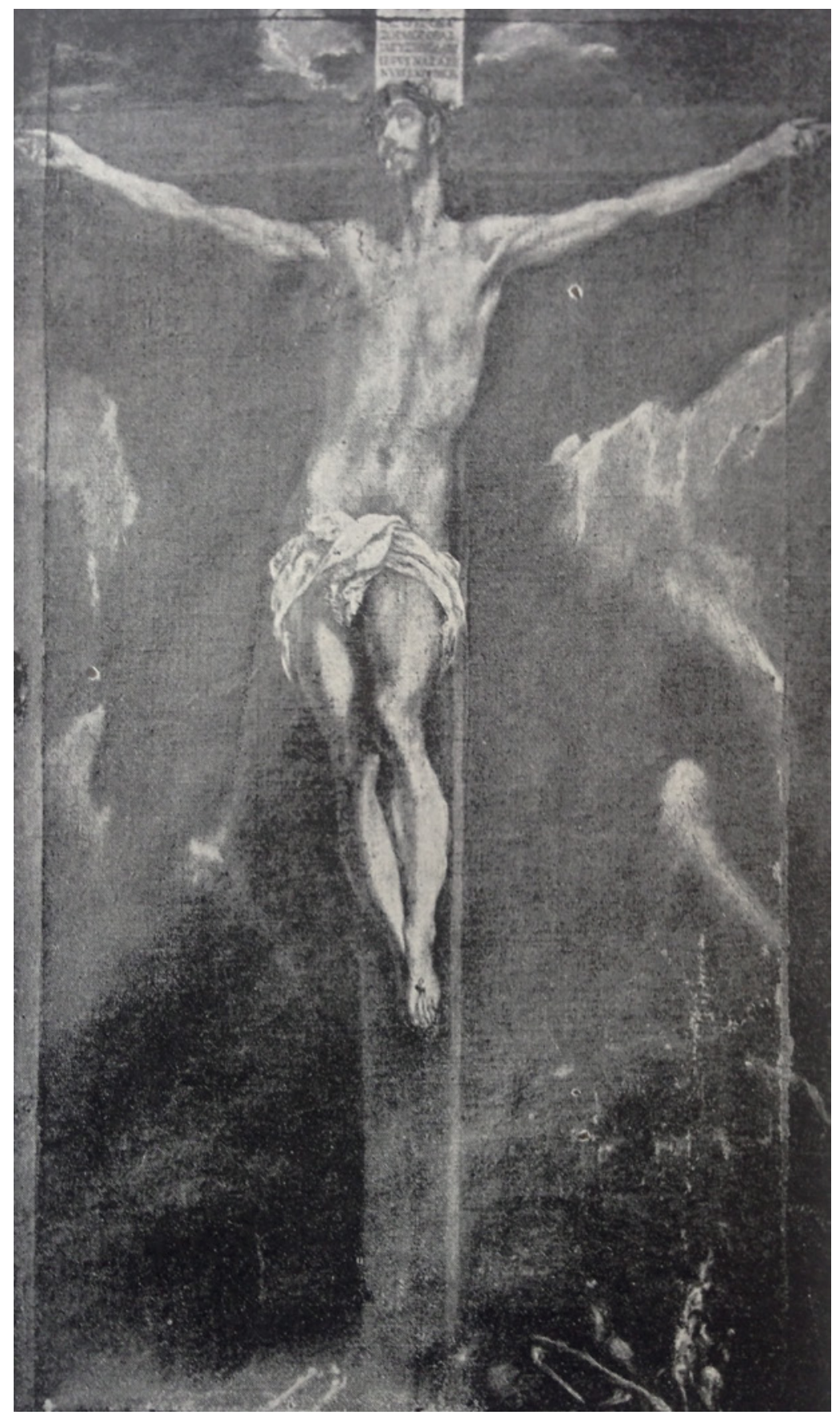

FIGURE 4.9 El Greco, Crucifixion, 1604-14, as illustrated in Manuel Bartolomé Cossío, El Greco (Madrid: Victoriano Suárez, 1908) 
investment. ${ }^{78}$ Their works were indeed modestly priced, indicative of a group of not-yet-established artists who wished to entice collectors with relatively small disposable incomes. Conder's works sold for around £25-50 in 1898-1909 and William Orpen's The Mirror made an appearance in Agnew's stock books for as little as $£_{35}$ in $1901 .{ }^{79}$ The cross-fertilisation between the old masters market and artistic practice, however, was not solely a matter of a commercially oriented critical discourse, but rather it was the product of complex dynamics and undeniable ties. In fact, the younger artists were not merely responding to a booming old masters market but they were also actively participating in the circumstances that created it. This process of amalgamation was intensified by the multiple roles of those involved, as the professional boundaries between dealers, critics and artists were fluid. For instance, artists such as James Kerr-Lawson and William Rothenstein worked as art dealers and dealt in old masters and contemporary art alike; conversely, several art dealers, such as Robert Ross and Robert Dell, were critics too, and they wrote about, and dealt with, contemporary art as well as old masters. ${ }^{80}$ The art of the past and modern British works shared commercial exhibition spaces, were commented upon by the same writers, were judged according to the same aesthetic canons and fulfilled the same function of simultaneously countering, supporting and illustrating the development of national art.

Such enmeshment of criticism, commerce and artistic practice is illustrated in a prominent art periodical of the time, The Burlington Magazine. This journal aimed to broaden the horizons of British art with recourse to cosmopolitanism, sought through the comparison with the art of the European past and links with international scholars and periodicals. ${ }^{81}$ The Burlington was also deeply involved with contemporary artistic practice: its engagement, with Fry,

78 Holmes, Pictures, 34-41.

79 I have explored Conder's prices in: Pezzini, "New Documents," 19-29. Orpen's The Mirror is recorded as acquired from D.C. Thompson in March 1901 for $£_{35}$ and sold to General Mc Culloch for the same amount. Agnew's Stock Books, vol. 8, stock no. 9766, National Gallery Archive, London, NGA27/1/1/10.

8o I have investigated the cross-fertilisation between old masters and contemporary art market in: Barbara Pezzini, "More Adey, the Carfax Gallery and The Burlington Magazine," BM 153 (2011): 806-14; Id., "The Value and Price of the Renaissance: Robert Ross and the Satire of Connoisseurship," in La Storia e la Critica: Atti della Giornata di Studi per Festeggiare Antonino Caleca, eds. Lorenzo Carletti and Gabriella Garzella (Pisa: Pacini, 2016), 179-86.

81 On the early history of The Burlington Magazine, see: Helen Rees Leahy, "For Connoisseurs: The Burlington Magazine," in Art History and its Institutions, ed. Elizabeth Mansfield (London and New York: Routledge, 2002), 231-45; Caroline Elam, "A More and More Important Work: Roger Fry and The Burlington Magazine," BM 145 (2003): 142-52; Pezzini, "More Adey," 154-83, with bibliography. 
in the diffusion of contemporary French art in the 1910s, in parallel with Fry's two post-impressionist exhibitions, has been amply treated. ${ }^{82}$ But —and this is still an unexplored subject - the publication had an interest in contemporary art even in its early years, when Robert Dell and Charles Holmes were its editors. In fact, I argue that an acute interest in contemporary British art and its position within the historical national canon rested at the very heart of the Burlington's inception. The very first editorial of this magazine, unsigned but most likely written by its first editor, Dell, and published in March 1903, stated that contemporary art, if it was not the main subject of this magazine, it was nevertheless its main raison d'être..$^{83}$ The journal positioned itself against much of contemporary British art, a mere sophistication that emitted 'odour of false sentiment' and a cheap substitute for real thought and feeling. Dell pointed the finger sternly towards the Royal Academy summer exhibitions, where artists dealt 'in fatuities, mild parlour jests, tit-bits of curiosities' with sentimental titles such as A Baby Crab and A Merry Jest. ${ }^{84}$ The rigorous study of the art of the past was proposed by Dell as a remedy for this situation of decadence in contemporary art.

In the very early days of the Burlington, contemporary art was often mentioned in commercial terms. As the old masters market had 'absorbed the public attention to the detriment of living men' for the wealthiest collectors, contemporary art was presented as the best investment for collectors of relatively modest means who could not afford to purchase old masters. ${ }^{85}$ Which living artists were on their way to becoming the old masters of the future? Which kind of contemporary art was worth collecting to make a worthy aesthetic as well as economic investment? Such topics were treated in several editorials and full-length articles in the Burlington, pieces that were either unsigned or hidden under initials, as these subjects were still considered controversial and the responsibility of their authorship did not wish to be claimed. For instance, in "What Modern Pictures Are Worth Collecting," published in November 1904 by the as-yet-unknown P.A. (Painter Anonymous? Perhaps Charles Holmes?), the author guided buyers in the purchase of contemporary art as a long-term financial investment. ${ }^{86}$ In February 1905 an editorial on the prospect of contemporary painting mentioned the commercial success of Conder, whose fame was connected with the current fashion for eighteenth-century painting

82 Benedict Nicolson, "Post-Impressionism and Roger Fry," BM 93 (1951): 10-5; Anon., "Cézanne and The Burlington Magazine," BM 138 (1996): 67-8.

83 [Robert Dell], "Editorial," $B M_{1}$ (March 1903): $3^{-5}$.

84 Id., 5 .

85 Anon., "The Prospects of Contemporary Painting," BM 6 (1905): 341-4.

86 P.A., "What Modern Pictures Are Worth Collecting," BM 6 (1904): 108-10. 
and domestic decoration. ${ }^{87}$ The Burlington reviewed commercial exhibitions of independent artists' associations at length in addition to shows held in private galleries. Also in these reviews modern art was compared with that of the European old masters. 'A Modern Painter', the anonymous author of a $1907 \mathrm{se}-$ ries of five articles entitled "The Case for Modern Painting," chose to illustrate prominently a tondo by Shannon, Hermes and the Infant Bacchus (Fig. 4.10). ${ }^{88}$ This work, finished in 1906 and recently exhibited in London, was inspired by the old masters in the choice of its format, subject and style. Its main reference point was Titian, whose Bacchus and Ariadne had been in the National Gallery's collection since 1826. Shannon's quote was noted by the reviewer, according to whom this painting belonged to 'the Venetian room of Trafalgar Square' where it would be able to quite hold its own 'even in that exalted society. 89 This was a particularly telling remark about the modernity of the old masters' revival, coming from a writer who identified himself as 'A Modern Painter'. In May 1909 Holmes commented favourably on another contemporary work, Smiling Woman by Augustus John (London, Tate Gallery), recently exhibited at the New Gallery, and compared it to early Florentine portraiture, not as a mere academic copy, but rather as a work that participated in the spirit of the art of Botticelli, Pollaiuolo and Andrea del Castagno, and defined it 'a gipsy Gioconda. ${ }^{90}$ The Burlington thus inscribed a selection of contemporary British artists in a network of international artistic references, mainly to the European old masters, in order to emphasise and boost the commercial potential and market value of this new generation of artists.

Not all writers, however, agreed with the adoption of the old European masters as a source for modern inspiration. In 1906 the art critic and artist Bernard

87 'Now eighteenth-century furniture of a certain outward appearance of authenticity is within the reach of many who are no more than well-to-do, and cannot afford the fine works by the old masters which are its conventional accompaniments. Modern paintings are not supposed to look well in such an environment, and so they are no longer purchased by many of the class which bought them most freely in the past. In this quarter artists will have to wait till the caprice of fashion introduces some style of furnishing which needs oil paintings and water colours for its completion. Meanwhile those who, like that gifted colourist Mr. Conder, paint in a manner which harmonizes perfectly with the style of the French eighteenth century will reap the richest harvest.' Cited from: Anon., "The Prospects," 341-4.

88 The title of this work, Hermes and the Infant Bacchus, as given in the 1906 Burlington Magazine, combines Greek and Roman mythologies: Hermes is the Greek form of Mercury and Bacchus is the Latin name of Dyonisos. Another version of this work in the Tate Gallery, London.

89 A Modern Painter, "The Case for Modern Painting," $B M 11$ (1907): 3-13.

90 Charles Holmes, "Two Modern Pictures," BM 15 (1909): 75-81. 


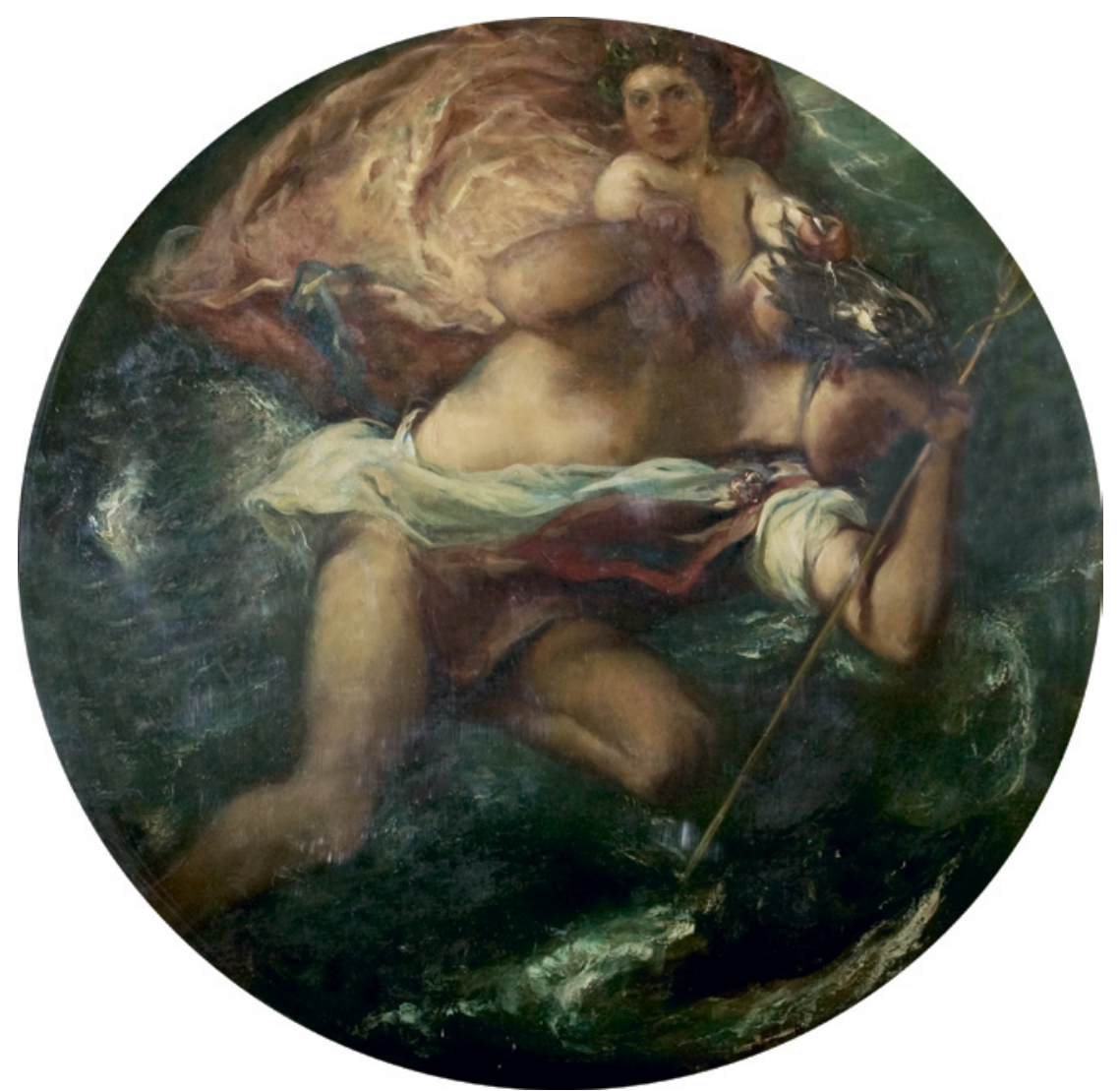

FIGURE 4.10 Charles Shannon, Hermes and the Infant Bacchus, 1902-06. Oil on canvas, $10.7 \times 10.7 \mathrm{~cm}$. Lincoln, Usher Gallery

(C) USHER GALLERY

Sickert, brother of the better-known painter Walter, in two important articles for the Burlington - "Independent Art of To-Day" and "Modern Painters in 1906 "- questioned the stylistic choices of what he dubbed the 'archaistic' current. For instance, Sickert found Shannon's overt use of the quote tiresome. In discussing The Mill Pond (Fig. 4.5), he stated: 'These youths are not doing anything in particular. They have posed to Titian and to Andrea del Sarto, they have posed to Watts and Burne-Jones, and now they are posing to Mr. Shannon, and are heartily tired of the business. ${ }^{91}$ Sickert accused British artists of fleeing reality in favour of mere escapism: 'the eclectic reconstruction of past visions is misleading as it gives no insights into our pursuits and our appearance

$91 \quad$ Sickert, "Independent Art," 381-4. 
at present in the year 1906.92 He unfavourably compared such a choice with modern French painting, which he believed to be a more valid alternative because it was fully grounded in the present.

\section{Conclusion: The European Idiom of British Painting}

By choosing French painting, Sickert had bet on the winning horse..$^{93}$ As Taylor has pointed out, the majority of art criticism at the beginning of the twentieth century veered 'towards the canonisation of French art as the only serious art. ${ }^{\prime 94}$ French painting-namely, impressionism, post-impressionism and the avant-garde - was to become the dominant critical paradigm for modern art. Mark Cheetham has traced the Francophile bent in Fry's writings, noting how Fry (and, we can add, Bell) assessed historical and contemporary British art in terms of his own version of French standards, and how Fry defined universal art as a particular line of post-impressionist practice. ${ }^{95}$ To this unquestionably correct observation, it must be added that Fry made constant reference to a historical paradigm of art. In the course of the twentieth century, the two canons separated: modern French art became the litmus test for modern British art, and the European old masters for historic national painting. Such a separation, however, was still in fieri in the early twentieth century, when modern British art was judged according to both the modern French standard and the old masters paradigm. Caught between European-especially Italian, Spanish and Dutch-old masters in the past and French modern art in the present, contemporary British national art was seen as a secondary event in European painting, neither continuing a long-standing tradition nor proposing an innovation. The presence of an integrated, formidably successful old masters market and of a paradigm dominated by the European old masters can be seen, in such a logic, as a stifling force in the formation of an autonomous visual language in Britain. Yet there is another possible reading. A wider understanding of the intertwining of the art market, scholarship and artistic practice

92 Bernard Sickert, "Modern Painters in 1906," BM 9 (1906): 221-4.

93 For instance, the acquisition policy of the Tate Gallery and its moderate Francophile bent has been examined in: Taylor, Art for the Nation, 132-66; Alexandra MacGilp, "The London Art World and the Formation of a National Collection of Modern British and Foreign Works at Tate 1926-1946" (PhD diss., University of Reading, 2010).

94 Taylor, Art for the Nation, 140.

95 Mark A. Cheetham, Artwriting, Nation, and Cosmopolitanism in Britain: The 'Englishness' of English Art Theory since the Eighteenth Century (Farnham - Burlington: Ashgate, 2012), 86-9o. 
contributes to the revision of a dominant idea of this period as stylistically insular and parochial and dominated by an excessive nostalgia of the past. On the contrary, in parallel with a thriving art market and growing scholarly investigations, it could be argued that British artists of the turn of the century aimed to live up to the comparison with the old masters and created a diverse cosmopolitan language, part Whistlerian, part French, and significantly inspired by the European art of the past, to generate critical, commercial and popular interest. This art was not modernist, in the sense that it did not present the extreme simplifications and distortions that we have come to associate with that movement, and certainly had strong stylistic connections with British finde-siècle aestheticism, but that does not mean that it was not representative of topical concerns. At least until 1910, as shown in the Whitechapel exhibition Twenty Years of British Art, this current represented a vital element of modern art in Britain and possessed enough of its own character to be distinctive and hence worthy of independent consideration. Neither did this current represent pictorial conservatism. It was, instead, the expression of a proactive return to the European art of the past through the recuperation of themes and devices. Later avant-garde artists portrayed themselves as extreme innovators who broke with tradition, and yet the art of the past was strongly present in their work with recourse to late medieval and early Renaissance "primitivism." They too were indebted to an inquisitive approach to the art of the past that expressed itself not only through visual works but also with commercial exhibitions and historical studies as it developed in the generation that flourished at the turn of the twentieth century.

\section{References}

A Modern Painter. "The Case for Modern Painting." The Burlington Magazine 11 (April 1907): 3-13.

A.P. "What Modern Pictures Are Worth Collecting." The Burlington Magazine 6 (November 1904): 108-10.

Anderson, Benedict. Imagined Communities: Reflections on the Origin and Spread of Nationalism. (London - New York: Verso, 1983.

Anon. "The Prospect of Contemporary Painting." The Burlington Magazine 6 (February 1905): 341-4.

Anon. "Modern Pictures in the Saleroom." The Burlington Magazine 13 (May 1908): $67-9$.

Anon. "Death of Mr Martin Colnaghi." Daily Telegraph, 25 June 1908: 8.

Anon. "London News." American Art News 7 (16 January 1909), 5. 
Anon. "Picture Sales." The Connoisseur 32 (1912): 267.

Anon. "Cézanne and The Burlington Magazine." The Burlington Magazine 138 (February 1996): 67-8.

Anon. “A Rare Art Dealer." The Guardian, 8 October 1932: 12-3.

Avery-Quash, Susanna. "Botticelli and Victorian Art Collecting." In Botticelli Reimagined, edited by Mark Evans and Stefan Weppelmann, 294-310. London: V\&A Publishing, 2016.

Bayer, Thomas M., and John R. Page. The Development of the Art Market in England: Money as Muse 1730-1900. London: Pickering \& Chatto, 2011.

Bell, Clive. Art. London: Chatto \& Windus, 1914.

Calloway, Stephen. "Tired Hedonists, the Decadence of the Aesthetic Movement." In The Cult of Beauty: The Aesthetic Movement 1860-189o, edited by Stephen Calloway, 224-35. London: Victoria and Albert Museum Publications, 2011.

Carman, Jillian. Uplifting the Colonial Philistine. Johannesburg: Wits University Press, 2006.

Cheetham, Mark A.Artwriting, Nation, and Cosmopolitanism in Britain: The 'Englishness' of English Art Theory since the Eighteenth Century. Farnham - Burlington: Ashgate, 2012.

Clarke, Meaghan. "The Art Press at the Fin-de-Siècle: Women, Collecting and Connoisseurship." Visual Resources 31 (April 2015): 15-30.

Cossío, Manuel B. El Greco. Madrid: Suarez, 1908.

Cust, Lionel. Historical and Descriptive Catalogue of the Pictures, Busts, \&c. in the National Portrait Gallery. London: HM Stationery Office, 1898 and 1900.

Delaney, J.G.P. Charles Ricketts: A Biography. Oxford: Clarendon Press, 1990.

[Dell, Robert]. "Editorial." The Burlington Magazine 1 (March 1903): 3-5.

Elam, Caroline. "A More and More Important Work: Roger Fry and The Burlington Magazine." The Burlington Magazine 145 (March 2003): 142-52.

Eliot, Simon. "From Few and Expensive to Many and Cheap: The British Book Market 1800-1890." In A Companion to the History of the Book, edited by Simon Eliot and Jonathan Rose, 291-302. Malden: Blackwell, 2007.

Fletcher, Pamela. "Shopping for Art: The Rise of the Commercial Art Gallery, 1850s189os." In The Rise of the Modern Art Market in London, 1850-1939, edited by Pamela Fletcher and Anne Helmreich, 47-64. Manchester: Manchester University Press, 2011.

Fraser, Hilary. The Victorians and Renaissance Italy. Oxford: Wiley-Blackwell, 1992.

[Fry, Roger]. "Exhibitions." The Athenaeum (17 May 1902): 632.

Fry, Roger. "The Umbrian Exhibition at the Burlington Fine Arts Club." The Burlington Magazine 16 (February 1910): 267-74.

Fry, Roger. Reflections on British Painting. London: Faber \& Faber, 1934.

Fry, Roger. French, Flemish and British Art. London: Chatto \& Windus, 1951. 
Gennari Santori, Flaminia. The Melancholy of Masterpieces: Old Master Paintings in America 19oo-1914. Milan: 5 Continents, 2003.

Harrison, Charles. English Art and Modernism. London: Allan Lane, 1981.

Helmreich, Anne, and Pamela Fletcher. "The Periodical and the Art Market: Investigating the 'Dealer-Critic System' in Victorian England." Victorian Periodicals Review 41 (2008): 323-51.

Helmreich, Anne. "The Death of the Victorian Art Periodical." Visual Resources 26 (September 2010): 242-53.

Helmreich, Anne. "Traversing Objects: The London Art Market at the Turn of the Twentieth Century." In Marketing Art in the British Isles 1700 to the Present, edited by Charlotte Gould and Sophie Mesplède, 135-45. Farnham - Burlington: Ashgate, 2012.

Holmes, Charles. Pictures and Picture Collecting. London: A. Treherne \& Co., 1903.

Holmes, Charles. “Two Modern Pictures." The Burlington Magazine 15 (May 1909): $75^{-81 .}$

Hotta-Lister, Ayako, and Ian Nish, eds. Commerce and Culture at the 1910 Japan-British Exhibition: Centenary Perspectives. London: Global Oriental, 2012.

Howard, Jeremy. "Art, Commerce, and Scholarship: The Friendship between Otto Gutekunst of Colnaghi and Bernard Berenson." In Bernard Berenson: Formation and Heritage, edited by Joseph Connors and Louis A. Waldman, 33-68. Princeton: Harvard University Press, 2014.

Koval, Anne. “The 'Artists' Have Come Out and the 'British' Remain: The Whistler Faction at the Society of British Artists." In After the Pre-Raphaelites: Art and Aestheticism in Victorian England, edited by Elizabeth Prettejohn, 90-114. New Brunswick: Rutgers University Press, 1999.

Laing, Donald A. Roger Fry: An Annotated Bibliography of the Published Writings. New York - London: Garland Publishing, 1979.

Law, John E., and Lene Østermark-Johansen, eds. Victorian and Edwardian Responses to the Italian Renaissance. Burlington - Farnham: Ashgate, 2005.

MacColl, Dugald Sutherland. Nineteenth Century Art. London: Macmillan, 1902.

MacGilp, Alexandra. "The London Art World and the Formation of a National Collection of Modern British and Foreign Works at Tate 1926-1946." PhD diss., University of Reading, 2010.

McConkey, Kenneth. Memory and Desire: Painting in Britain and Ireland at the Turn of the Twentieth Century. Burlington - London: Ashgate, 2002.

McKeown, William C. "Charles Shannon in the House of Delia: A Theme from Tibullus." The Burlington Magazine 152 (May 2010): 303-6.

Mostyn-Owen, William. Bibliografia di Bernard Berenson. Milano: Electa, 1955.

Nicolson, Benedict. "Post-Impressionism and Roger Fry." The Burlington Magazine 93 (January 1951): 10-5. 
Pezzini, Barbara. "More Adey, the Carfax Gallery and The Burlington Magazine." The Burlington Magazine 153 (December 2011): 806-14.

Pezzini, Barbara. "New Documents Regarding the 1902 'Fans and Other Paintings on Silk by Charles Conder' Exhibition at the Carfax Gallery." British Art Journal 13 (Autumn 2012): 19-29.

Pezzini, Barbara. "The 1912 Futurist Exhibition at the Sackville Gallery, London: An Avant-garde Show within the Old Masters Trade." The Burlington Magazine 155 (July 2013): 471-9.

Pezzini, Barbara. "The Burlington Magazine, The Burlington Gazette and The Connoisseur: The Art Periodical and the Market for Old-Master Paintings in Edwardian London." Visual Resources 29 (September 2013): 154-83.

Pezzini, Barbara, and Alycen Mitchell. "Marketing Miss Charlotte: Martin Colnaghi and George Romney at the Turn of the Twentieth Century." Transactions of the Romney Society 19 (2014): 4-11.

Pezzini, Barbara. "The Value and Price of the Renaissance: Robert Ross and the Satire of Connoisseurship." In La Storia e la Critica: Atti della Giornata di Studi per Festeggiare Antonino Caleca, edited by Lorenzo Carletti and Gabriella Garzella, 179-86. Pisa: Pacini, 2016.

Phillips, Claude. Criticisms of Exhibitions of Pictures Held in London 1869-1912. London: privately printed, 1912.

Prettejohn, Elizabeth. "Walter Pater and Aesthetic Painting." In After the Pre-Raphaelites: Art and Aestheticism in Victorian England, edited by Elizabeth Prettejohn, 36-58. New Brunswick: Rutgers University Press, 1999.

Prettejohn, Elizabeth. Modern Painters, Old Masters: The Art of Imitation from the PreRaphaelites to the First World War. New Haven - London: Yale University Press, 2017. Rees Leahy, Helen. "For Connoisseurs: The Burlington Magazine." In Art History and its Institutions, edited by Elizabeth Mansfield, 231-45. London - New York: Routledge, 2002.

Reitlinger, Gerard. The Economics of Taste. 3 vols. London: Barrie and Rockliff, 1961. Report of the Committee of Trustees of the National Gallery Appointed by the Trustees to Enquire into the Retention of Important Pictures in this Country and Other Matters Connected with the National Art Collections. London: HMSO, 1915.

R.M. [Rothschild Max]. “The Picture Sales.” The Burlington Gazette 1 (May 1903): 47.

Robins Gruetzner, Anna. "Marketing Post-Impressionism: Roger Fry's Commercial Exhibitions." In The Rise of the Modern Art Market in London, 1850-1939, edited by Pamela Fletcher and Anne Helmreich, 85-97. Manchester: Manchester University Press, 2011.

Rose, Jonathan. "Modernity and print I: Britain 1890-1970." In A Companion to the History of the Book, edited by Simon Eliot and Jonathan Rose, 341-53. Malden: Blackwell, 2007. 
Samuels, Ernest, and Jayne Samuels. Bernard Berenson: The Making of a Legend. Princeton: Harvard University Press, 1987.

Shaw, Samuel. "The New Ideal Shop: Founding the Carfax Gallery, c. 1898-1902." The British Art Journal 13 (Autumn 2012): 35-43.

Shaw, Samuel. "Scarcely a Scholar: William Rothenstein and the Artist as Art-Writer in English Periodicals, ca. 1890-1910." Visual Resources 31 (April 2015): 45-60.

Sickert, Bernard. "Independent Art of To-Day." The Burlington Magazine 8 (March 1906): 381-84.

Sickert, Bernard. "Modern Painters in 1906." The Burlington Magazine 9 (July 1906): 221-4.

Spalding, Frances. The Tate: A History. London: Tate Gallery Publishing, 1998.

Spencer, Robin. "Whistler, Swinburne and Art for Art's Sake." In After the Pre-Raphaelites: Art and Aestheticism in Victorian England, edited by Elizabeth Prettejohn, 59-89. New Brunswick: Rutgers University Press, 1999.

Stokes, John. In the Nineties. Chicago: University of Chicago Press, 1990.

Swanson, Vern G. The Biography and Catalogue Raisonné of the Paintings of Sir Lawrence Alma-Tadema. London: Garton \& Co., 1990.

Taylor, Brandon. Art for the Nation: Exhibitions and the London Public, 1747-2001. Manchester: Manchester University Press, 1999.

Ten-Doesschate-Chu, Petra. "Siegfried Bing and Charles Conder: The Many Faces of New Art." In Twenty-First-Century Perspectives on Nineteenth-Century Art: Essays in Honor of Gabriel P. Weisberg, edited by Laurinda S. Dixon and Petra ten-Doesschate Chu, 133-40. Newark: University of Delaware Press, 2008.

Tickner, Lisa. Modern Life and Modern Subjects: British Art in the Early Twentieth Century. New Haven - London: Yale University Press, 2000.

Tucker, Paul. "Responsible Outsider: Charles Fairfax Murray and the South Kensington Museum." Journal of the History of Collections 14 (2002): 115-37.

Tucker, Paul. "Eyesight, Knowledge, Argument: Charles Fairfax Murray on 'Scientific' Connoisseurship." Studi di Memofonte 12 (2014): 106-43.

Vision and Design: The Life, Work and Influence of Roger Fry, 1866-1934. London: Arts Council Catalogues, 1966.

Weedon, Alexis. Victorian Publishing: The Economics of Book Production for a Mass Market 1836-1916. Aldershot: Ashgate, 2003.

Whitehead, Christopher. The Public Art Museum in Nineteenth Century Britain: The Development of the National Gallery. Aldershot: Ashgate, 2005.

Witt, Robert. The Nation and its Art Treasures. London: Heinemann, 1911. 